\title{
Implications of the permanent El Niño teleconnection "blueprint" for past global and North American hydroclimatology
}

\author{
A. Goldner ${ }^{1}$, M. Huber ${ }^{1}$, N. Diffenbaugh ${ }^{2}$, and R. Caballero ${ }^{3}$ \\ ${ }^{1}$ Earth and Atmospheric Sciences, Purdue University, USA \\ ${ }^{2}$ School Earth of Sciences, Stanford University, USA \\ ${ }^{3}$ Meteorology and Climate Centre, School of Mathematical Sciences, University College Dublin, Dublin, Ireland
}

Received: 6 December 2010 - Published in Clim. Past Discuss.: 17 January 2011

Revised: 17 June 2011 - Accepted: 23 June 2011 - Published: 13 July 2011

\begin{abstract}
Substantial evidence exists for wetter-thanmodern continental conditions in North America during the pre-Quaternary warm climate intervals. This is in apparent conflict with the robust global prediction for future climate change of a northward expansion of the subtropical dry zones that should drive aridification of many semiarid regions. Indeed, areas of expected future aridification include much of western North America, where extensive paleoenvironmental records are documented to have been much wetter before the onset of Quaternary ice ages. It has also been proposed that climates previous to the Quaternary may have been characterized as being in a state with warmer-than-modern eastern equatorial sea surface temperatures (SSTs). Because equatorial Pacific SSTs exert strong controls on midlatitude atmospheric circulation and the global hydrologic cycle, the teleconnected response from this permanent El Niño-like mean state has been proposed as a useful analogue model, or "blueprint", for understanding global climatological anomalies in the past. The present study quantitatively explores the implications of this blueprint for past climates with a specific focus on the Miocene and Pliocene, using a global climate model (CAM3.0) and a nested high-resolution climate model (RegCM3) to study the hydrologic impacts on global and North American climate of a change in mean SSTs resembling that which occurs during modern El Niño events. We find that the global circulation response to a permanent El Niño resembles a large, long El Niño event. This state also exhibits equatorial super-rotation, which would represent a fundamental change to the tropical circulations. We also find a southward shift in winter storm tracks in the Pacific and Atlantic, which affects precipitation and temperature over the mid-latitudes. In addition, summertime precipitation increases over the majority of the continental United
\end{abstract}

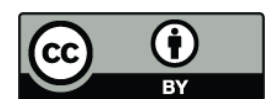

Correspondence to: A. Goldner (agoldner@purdue.edu)
States. These increases in precipitation are controlled by shifts in the subtropical jet and secondary atmospheric feedbacks. Based on these results and the data proxy comparison, we conclude that a permanent El Niño like state is one potential explanation of wetter-than-modern conditions observed in paleoclimate-proxy records, particularly over the western United States.

\section{Introduction}

It is well established that pre-Quaternary global climates were warmer than modern and had smaller equator-to-pole temperature gradients (Zachos et al., 2001). These climates are also characterized as being wetter (Wolfe, 1994; Retallack, 2007). This should be surprising given that our best current understanding of global hydrology suggests an increase in the size of arid-to-semi-arid zones in a warmer world (Held and Soden, 2006). Here we demonstrate that in warm climates of the Neogene $~ 23-2.58$ million years ago (m.a.), paleoclimate proxy evidence does indeed support wetter than modern conditions, including in the modern semi-arid regions. Changes in tropical Pacific sea surface temperatures (SSTs) provide one possible explanation of this enigmatic feature.

Within the Neogene, the early and middle Miocene tropical SST regions were warmer than modern by $1-2{ }^{\circ} \mathrm{C}$ (Stewart et. al., 2004; You et al., 2009) and close to modern values in the late Miocene (Steppuhn et al., 2007), but spatial coverage is lacking especially in the eastern equatorial $\mathrm{Pa}-$ cific (EEP). Also, terrestrial temperatures in the mid-latitudes are recorded as warmer than modern in the early and middle Miocene (Wolfe, 1994; Uhl et al., 2006; Micheels et al., 2007). In the early Pliocene, the tropical SSTs are recorded as up to $8^{\circ} \mathrm{C}$ (Dekens et al., 2007; Brierley et al., 2009; Brierley and Fedorov, 2010) warmer than modern, with continued warmth in the middle to late Pliocene (Dowsett, 1996).

Published by Copernicus Publications on behalf of the European Geosciences Union. 
Global temperatures during the middle Pliocene are reconstructed as $2-3{ }^{\circ} \mathrm{C}$ warmer globally compared with modern (Raymo et al., 1996), with warmer than modern mid-latitude regions (Thompson and Fleming, 1996).

These warmer periods are reconstructed as having wetter mid-latitude regions over North America (Thompson, 1991, 1996; Smith and Patterson, 1993; Smith, 1994; Wolfe, 1994, 1997; Axelrod, 1997), Europe (Jimenez-Moreno et al., 2010; Boyd, 2009), and South America (Zarate and Fasana, 1989). This includes many regions which are currently semiarid despite the fact that continental configurations were similar to modern values (Lyle et al., 2008; Haywood et al., 2004; Herold et al., 2008; You et al., 2009). Global climate models simulating future global warming show a poleward expansion of the margin of the Hadley cell and associated storm track moisture flux divergence, resulting in increased aridity near subtropical margins such as southwestern North America (Held and Soden, 2006; Seager et al., 2007; Seager and Vecchi, 2010; O'Gorman and Schneider, 2009). This response to elevated greenhouse forcing appears at odds with widespread evidence for wetter-than-modern and cooler conditions over North America (Smith, 1994; Thompson, 1991; Axelrod, 1997; Wolfe, 1997; Cronin and Dowsett, 1991), and wetter conditions over Europe (Jimenez-Moreno et al., 2010; Boyd, 2009) and Central South America (Zarate and Fasana, 1989) in the Neogene warm periods.

It is potentially informative to investigate climate in these pre-Quaternary warm intervals, as they may hold clues to the climate dynamics that will shape the response to elevated greenhouse forcing in the coming decades (Crowley, 1996; Raymo et al., 1996; Ravelo et al., 2004). There is a general scientific consensus that a warmer world is associated with a wider Hadley cell and displaced jet; data, theory, and models show a variable response of zonal sea level pressure and SST gradients in the Pacific, implying that the future state of the equatorial Pacific is uncertain (Karnauskas et al., 2008; Sang-Wook et al., 2009). Current teleconnection patterns suggest that the response of the tropical Pacific to global warming is likely critical in determining mid-latitude climate change. But there is currently no consensus from observations, theory, or models about whether a globally warmer world requires - or results in - a tropical Pacific mean state that is closer to a La Niña- or El Niño-like configuration.

One potential resolution to this regional aridity paradox is that these reconstructed wet regions in North America, Europe, and South America were under the influence of remote impacts from the equatorial Pacific (Molnar and Cane, 2002). Atmospheric teleconnections associated with tropical SST anomalies influence the hydrologic cycle over the western United States (US) on interannual-to-millennial time scales (Cook et al., 2004; Cole et al., 2002; Held and Soden, 2006; Fedorov et al., 2000; Chiang, 2009; Seager and Vecchi, 2010). Paleoclimate reconstructions and proxies for the Pliocene and Miocene indicate that the tropical Pacific during these periods may have been characterized as in a permanent
El Niño-like state (Philander and Fedorov, 2003; Ravelo et al., 2004; Brierley et al., 2009; Wara et al., 2005; Fedorov et al., 2006; Dekens et al., 2007, 2008; Molnar and Cane, 2002; Lyle et al., 2008) in which the EEP, as well as diverse upwelling zones like the Californian and Peru margin, were much warmer than modern and thermocline tilt and/or structure was much different than today. Various mechanisms have been invoked to explain these changes (Fedorov et al., 2010; Sriver and Huber, 2010) and we do not explore that issue here. Instead we investigate the potential hydrological cycle responses as a sensitivity study, assuming the existence of a permanent shift in SSTs of the form evidenced by long, observed El Niño events. The definition of permanent El Niño used in this study reflects changes in EEP interannual variability. Furthermore, we used fixed SSTs because current coupled models have not been able to reproduce a permanent El Niño (Haywood et al., 2007), except when forced with tropical cyclone winds which are currently not resolved in global climate models (Fedorov et al., 2010; Sriver and Huber, 2010).

Molnar and Cane (2002) argued that a permanent El Niñolike SST distribution might have had global, teleconnected effects on temperature and effective moisture that resemble those noted from proxy records in the Pliocene, thus providing a "blueprint" to explain many of the observed features of past climates. In Fig. 1 we have compiled Miocene and Pliocene proxy records which highlight the regions that are reconstructed as wetter or drier than modern. We note that the pattern in Fig. 1 does not closely resemble the "robust" pattern projected by models for the future, and part of our motivation is trying to explain this discrepancy.

In this study, we will investigate how a permanent El Niño affects the hydroclimate of western North America using both a global climate model and a nested high-resolution climate. To our knowledge, no climate modeling study has yet investigated how a permanent El Niño affects the hydroclimate of western North America using a high-resolution climate modeling system. Indeed, many of hydroclimatic features important for cold-season climate in North America can be understood by analyzing large-scale circulation features (Horel and Wallace, 1981; Trenberth et al., 1998). Alternatively, the warm-season atmospheric circulation is sensitive to regional- and local-scale processes that are not well resolved in global climate models (e.g., Castro et al., 2001; Diffenbaugh et al., 2005; Diffenbaugh and Ashfaq, 2010).

The inclusion of RegCM3 is especially motivated by previous research which has linked the gradual aridification over the western US in the Miocene to the uplift of mountain chains (Lyle et al., 2008). This result been called into question by new research which has shown that mountain uplift in the western US may have completed by the early Miocene (Clark et al., 2005; Chamberlain and Poage, 2000). To resolve dynamics over these topographically complex rain shadow regions and to understand their importance, RegCM3 will be used to explain summertime precipitation 

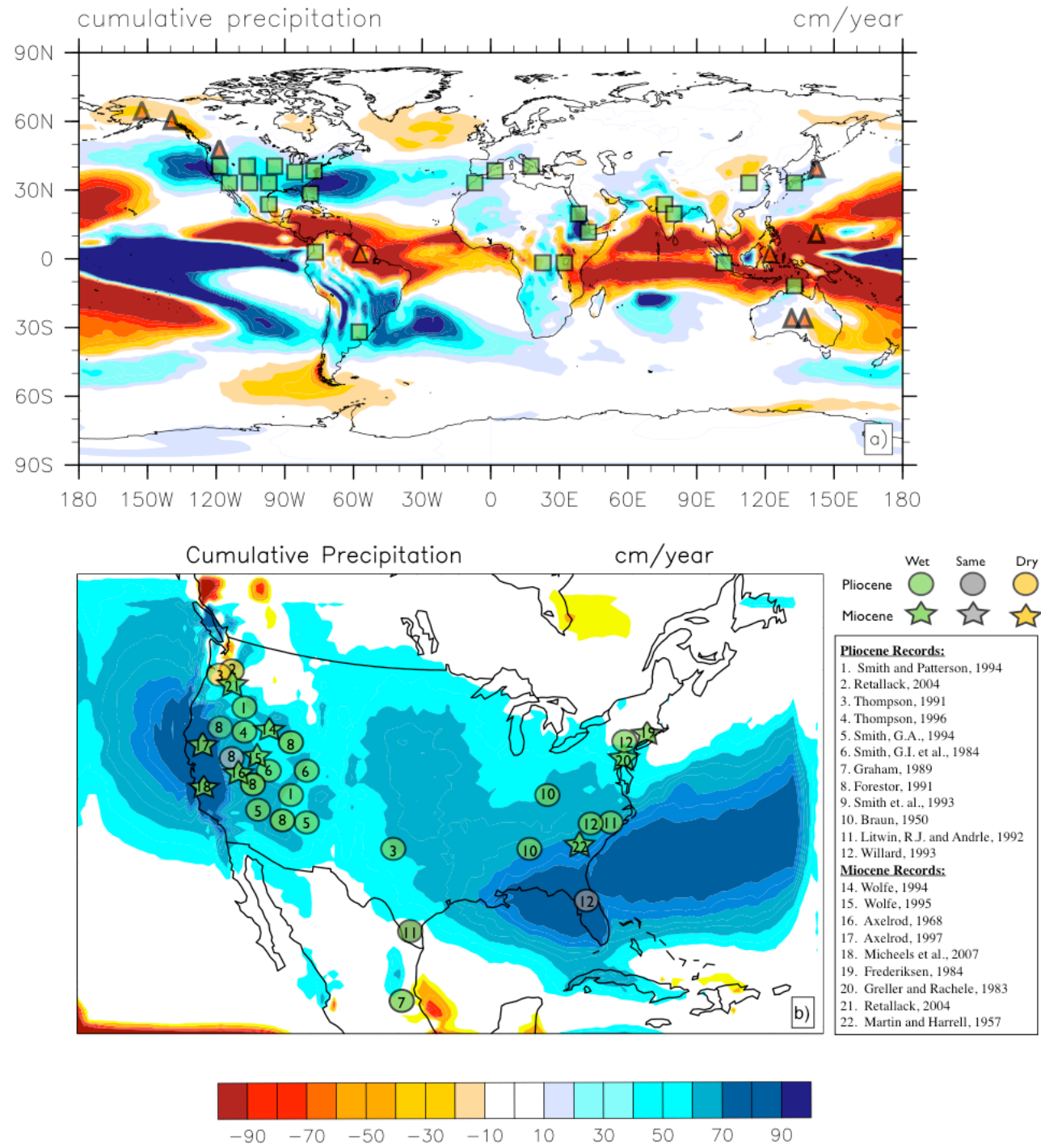

Fig. 1. (a) Summary of the modeled permanent El Niño annual precipitation anomaly (NINO minus MODERN) compared with Pliocene to Miocene proxy data estimates for suggested wet and dry regions, where green squares indicate wetter-than-modern and orange triangles indicate drier-than-modern. (b) RegCM3 modeled precipitation anomaly over US with a proxy compilation for the Pliocene and Miocene. The green dots represents proxy records which indicate wetter-than-modern and the orange dots indicate drier-than-modern during these Neogene warm climate intervals. The sites used in this compilation are found in the reference index and are cited with the appropriate numbering on the climate map. The green circles (wetter-Pliocene), green stars (wetter-Miocene), orange circles (drier-Pliocene), and orange stars (drier-Miocene).

over the United States. A detailed motivation for why we used RegCM3 in our analysis is described in Sect. 2.2.

A number of permanent El Niño simulations have been conducted in order to better understand ocean-atmosphere interactions, including those operating during past warm periods in Earth's history. Barreiro et al. (2006) removed the east-west SST gradient in the tropical Pacific and extended the tropical Pacific SSTs meridionally to understand the high-and mid-latitude temperature changes resulting from El Niño teleconnections. Vizcaino et al. (2010) altered the ocean heat transport in a slab ocean simulation, producing an El Niño-like state to explore El Niño teleconnections over the Northern Hemisphere. Shukla et al. (2009) imposed the large 1997/98 El Niño with Pliocene boundary conditions to explore global teleconnections within the Pliocene interval. Bonham et al. (2009) explored Pliocene mid-latitude teleconnections that developed due to altering the boundary conditions and found that altering vegetation induces precipitation feedbacks which match some of the Pliocene proxy record.

To further explore the hypothesis suggested by Molnar and Cane (2002), Huybers and Molnar (2007) used modern empirical estimates of high latitude temperature driven by El Niño events to understand the teleconnected response the Equatorial Pacific SSTs may have had on the gradual cooling 
in the high latitudes over the late Pliocene. Molnar and Cane (2007) used large modern El Niño events and associated teleconnections to compare with the Miocene and Pliocene proxy record. We are going to compliment and extend previous permanent El Niño simulations by focusing on the hydroclimatological aspects of the permanent El Niño blueprint and the degree to which past SST changes may have substantially perturbed global and regional effective moisture regimes.

This study is broken down into 5 sections: Section 2 describes model and methodology; Sect. 3 describes the global and regional temperature and precipitation patterns driven by a permanent El Niño, and how a permanent El Niño affects seasonal circulation patterns; Sect. 4 includes the discussion, and Sect. 5 presents the conclusions.

\section{Methods}

\subsection{High-resolution global climate model simulations}

We perform a series of prescribed-SST simulations using the National Center for Atmospheric Research (NCAR) Community Atmosphere Model (CAM3.0). CAM3.0 serves as the atmospheric component of the NCAR CCSM3 atmosphere-ocean general circulation model (AOGCM) (Collins et al., 2006). CAM3.0 employs the Hack convection scheme and spectral Eulerian dynamical core (Hack et al., 2006). We run CAM 3.0 at T85 spectral truncation, which is approximately $1.2^{\circ}$ resolution in the horizontal. When coupled to the ocean model, CAM3.0 captures the observed atmosphere response to ENSO forcing during the wintertime, even though the fully coupled model has problems reproducing the temporal variability of El Niño events (Joseph and Nigam, 2006). CAM3.0 also represents major features of the global hydrological cycle, even when responding to low frequency ENSO forcing (Hurrell et al., 2006; Hack et al., 2006). When run at T85 resolution, CAM3.0 shows significant improvements over the lower resolution version of CAM3.0, including improved representation of the monsoon circulation associated with improved resolution of topographic features (Meehl et al., 2006).

We create a permanent El Niño-like SST boundary condition by low-pass filtering the historical observed SST field and adding this anomaly to the 12 month climatology derived from Hurrell and Trenberth (1999). Observed SSTs taken from ERA-40 data set were linearly detrended and then low pass filtered to remove variability shorter than three years. A cross-correlation analysis with SST variations in the Niño 3.4 region was carried out and the resulting correlation field was the basis for the imposed SST anomalies. The crosscorrelation field was scaled by the local standard deviation of SST (i.e., regressed), and then the entire field was scaled by an arbitrary and globally constant coefficient designed to en- sure that the imposed SST anomaly in the EEP is comparable to the values reconstructed by Dekens et al. (2008). A threshold of $1 / 10$ of this constant coefficient was imposed to mask out small SST anomalies which are not likely to represent the core forcing of the permanent El Niño response. We then add the resulting constant SST anomaly to the NCAR 12 month climatological SST from Hurrell and Trenberth (1999). The permanent El Niño absolute SST distribution and anomaly can be seen in Fig. 2. This is a highly idealized permanent El Niño in which the anomaly is constant in all months in the repeating 12 month SST specified field.

The resulting SST patterns are broadly consistent with proxy based SST reconstructed for the equatorial Pacific in the Pliocene (Wara et al., 2005; Dekens et al., 2008) and are comparable in magnitude to those in Vizcaino et al. (2010). The low pass filtered SST anomaly was chosen to focus on SST configurations that are potentially long lived, i.e., not strongly damped on 1-2 yr time scales by ocean-atmosphere interaction. Because the anomaly was derived from the Niño 3.4 region, it projects both the "Modoki-type" (Fig. 2a) as described in Ashok et al. (2007) and "canonical" ENSO variability. The resulting SST field has peak SSTs along the dateline comparable with the 20th century SST trends (Collins et al., 2010; Sang-Wook et al., 2009). Futhermore, because our El Niño anomaly exhibits the "Modoki-type" and "canonical" ENSO variability, it induces both these dominant modes of El Niño induced circulation and precipitation anomalies as described in Trenberth and Smith (2009).

To enable a clean, single parameter sensitivity study we use modern sea ice distribution, land-sea orography, continental topography, orbital configuration, and land cover boundary conditions. Sea ice properties (fraction and thickness) in the specified SST version of CAM3 are normally derived from SST, but are unchanged in our simulations. We use modern day continents because El Niño teleconnections do not seem to be drastically effected by the movement of the continents (Huber and Caballero, 2003; Galeotti et al., 2010) and also to simplify the study. The point is to isolate the dominant patterns induced by a persistent El Niño. Non-SST influences were undoubtedly important in shaping features of the climate in past time periods (e.g., Haywood et al., 2004; Herold et al., 2008; You et al., 2009; Bonham et al., 2009). Nevertheless, the goal in the current study is to isolate the dominant patterns forced by a permanent shift in mean surface ocean conditions analogous to those seen during long El Niño events, with a specific focus of matching precipitation patterns over the continental United States.

The GCM simulations were run for $50 \mathrm{yr}$, with the last 20 used for the climatologies. All differences discussed are significant at the greater than $95 \%$ confidence interval based on a Student's t-test. In our simulations, the El Niño test case will be called NINO and the control case will be referred to as MODERN. 

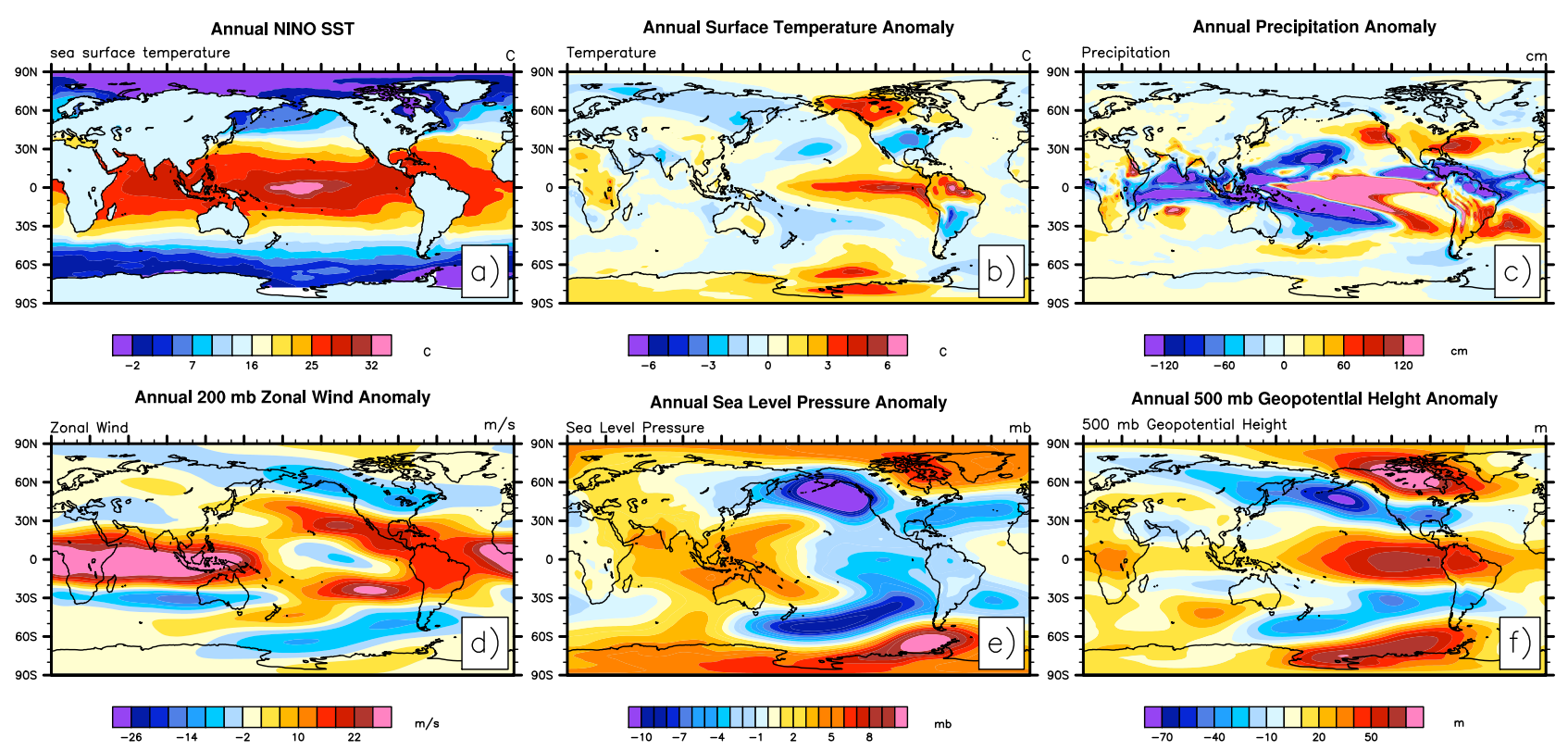

Fig. 2. (a) Specified mean annual SST distribution for the NINO case. The remaining fields are the mean annual anomalies between the NINO and MODERN case for basic atmospheric variables. (b) Surface temperature anomalies in ${ }^{\circ} \mathrm{C}$. (c) Cumulative precipitation anomaly in $\mathrm{cm} \mathrm{year}^{-1}$. (d) Zonal wind anomaly $\left(\mathrm{m} \mathrm{s}^{-1}\right.$ ) interpolated to the $200 \mathrm{mb}$ pressure level. (e) Sea level pressure anomaly in mb. (f) Geopotential height anomaly in meters.

\subsection{High-resolution nested climate model simulations}

In addition to the GCM experiments, we also nest the ICTP RegCM3 climate model (Pal et al., 2007) within the CAM3.0 global climate model. RegCM3 is a hydrostatic, sigma coordinate, primitive equation nested climate model. We employ the grid and parameterization options of Diffenbaugh et al. (2006) and Pal et al. (2000). In this configuration, the equal-area (horizontal) grid encompasses the continental US, with $55 \mathrm{~km}$ resolution in the horizontal and 18 levels in the vertical. We generate two RegCM3 simulations, one nested in the CAM3.0 modern control simulation, and one in the CAM3.0 NINO simulation. We integrate the RegCM3 simulations for 40 model years, with the last 20 used for analysis.

RegCM3 is able to capture the seasonal patterns of temperature and precipitation seen in observational data (Diffenbaugh et al., 2006; Walker and Diffenbaugh, 2009; Diffenbaugh and Ashfaq, 2010; Ashfaq et al., 2010), as well as the patterns of the hot, cold, and wet tails of the daily temperature and precipitation distributions (Walker and Diffenbaugh, 2009) and the pattern and magnitude of the historical hottestseason (Diffenbaugh and Ashfaq, 2010). RegCM3 also accurately simulates the mean and trends in peak snowmeltrunoff timing in the western US (Rauscher et al., 2008), as well as the pattern of Convective Available Potential Energy (CAPE) in the US (Trapp et al., 2007). Previous research using RegCM3 has been focused on the response of regional climate in North America to elevated greenhouse forcing and late-Quaternary orbital forcing, and suggests that fine-scale processes can regulate the response of a number of important regional climate features, including seasonal temperature (Diffenbaugh et al., 2006; Rauscher et al., 2008), extreme temperature and precipitation events (Diffenbaugh et al., 2005; White et al., 2006; Diffenbaugh et al., 2008), snow-melt runoff (Rauscher et al., 2008; Ashfaq et al., 2010), and atmosphere/soil-moisture coupling (Diffenbaugh et al., 2005; Ashfaq et al., 2010).

Given the previous work suggesting the importance of fine-scale processes in shaping the regional-scale climate response to changes in greenhouse and orbital forcing, we nest the RegCM3 high-resolution model within the CAM3.0 global model in order to test the role of fine-scale climate processes in shaping the regional hydroclimatic response to permanent El Niño-like SSTs. Our primary motivation for high-resolution nesting is to better resolve fine-scale processes that can be important for the response of regional climate to changes in global-scale forcing or changes in largescale climate dynamics.

Because of its higher resolution representation of the atmosphere and land surface, RegCM3 is able to better resolve fine-scale atmospheric features and climate system feedbacks than the lower resolution GCM (Diffenbaugh et al., 2005; Rauscher et al., 2008; Ashfaq et al., 2009). Of particular relevance for this study, RegCM3 is better able to resolve the regional precipitation features seen in the US when compared to CAM3.0 (Diffenbaugh et al., 2006) (Fig. 3). The differences in the simulation of baseline precipitation between the low- and high-resolution models are particularly 

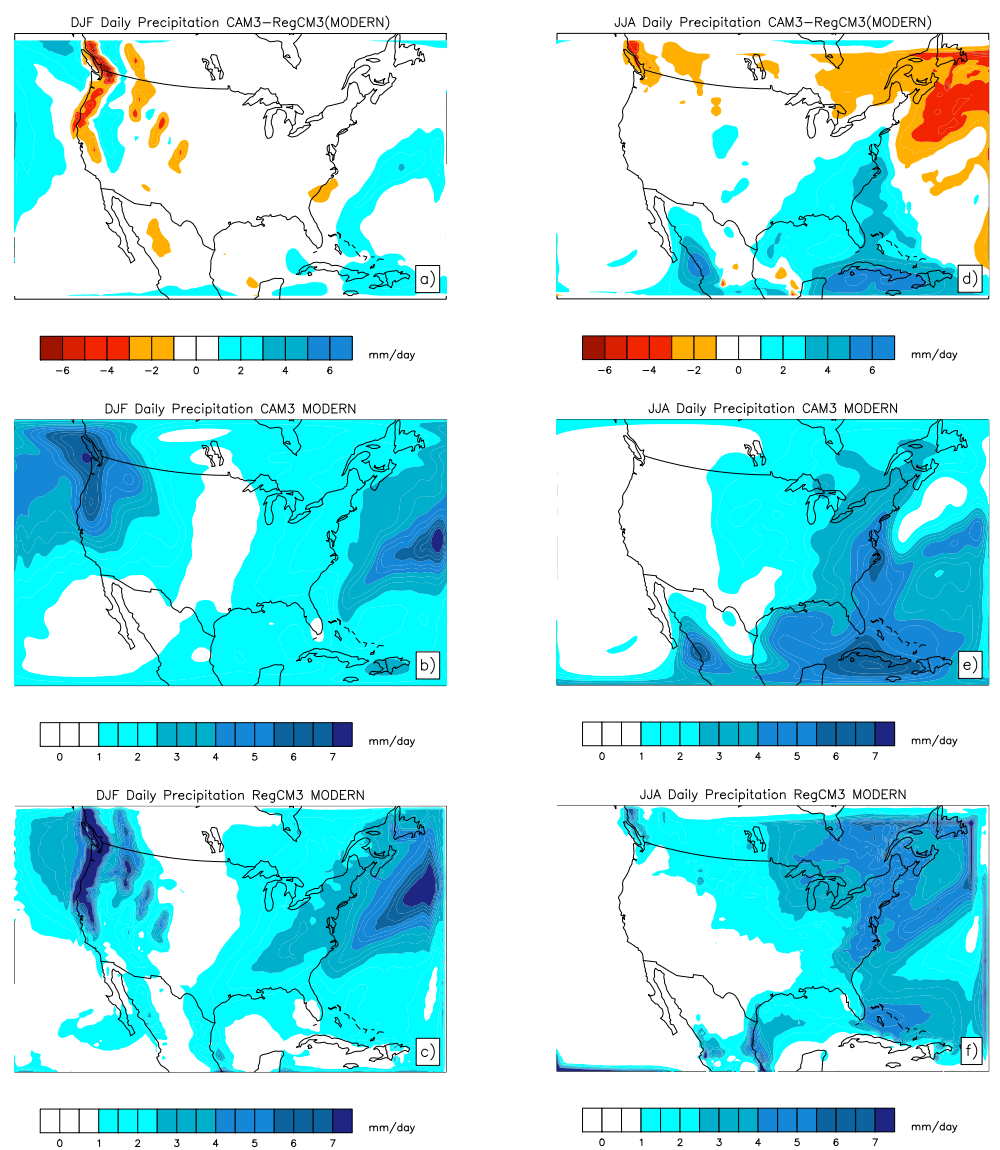

Fig. 3. Precipitation over North America in the T85 MODERN case and RegCM 3 case in (mm day ${ }^{-1}$ ) and anomalies thereof. (a) Boreal winter precipitation anomaly, (b) CAM3.0 boreal winter precipitation, (c) RegCM3 boreal winter precipitation, (d) CAM3.0 boreal summer precipitation anomaly, (e) CAM3.0 boreal summer precipitation, (f) RegCM3 boreal summer precipitation.

evident over areas for which proxy records of Pliocene and Miocene precipitation exist, including the topographically complex western US in winter and coastal areas of the eastern US in summer (Figs. 1 and 3). Given the geographic correspondence of the model differences with the locations of proxy observations, and the documented importance of fine-scale climate processes for the regional climate response in North America to changes in global radiative forcing and large-scale climate dynamics, we are motivated to use a highresolution climate modeling system to test the role of finescale climate processes in regulating the regional hydroclimate response to permanent El Niño-like SST conditions.

\section{Permanent El Niño results}

\subsection{Changes in global and annual means}

The permanent El Niño conditions increase simulated global mean temperature by $0.27^{\circ} \mathrm{C}$. This global temperature anomaly is similar to the approximately $0.2^{\circ} \mathrm{C}$ anomaly seen in the strong El Niño of 1997/1998 (Hansen et al., 2006). By design, the permanent El Niño SST pattern is consistent with a typical large El Niño event, as seen in the simulated NINO minus MODERN surface temperature anomaly (Fig. 2b).

As expected, the teleconnected terrestrial temperature response to the imposed El Niño SST anomaly closely resembles the pattern found in reanalysis products such as ERA40 during large El Niño events (Diaz et al., 2001). In addition, the high-latitude warmth seen over Canada and Alaska agrees with the results presented in the past permanent El Niño simulations (Barreiro et al., 2006; Shukla et al., 2009). Anomalies between the NINO and MODERN cases result in meridional stationary heat and water transport anomalies over the Pacific Northwest and Canada that transport more heat and water poleward (Figure not shown). These results agree with the meridional temperature and moisture advection anomalies presented in the permanent El Niño experiment of Vizcaino et al. (2010).

Global mean precipitation for the MODERN case is $103.76 \mathrm{~cm} \mathrm{year}^{-1}$, which is in close agreement with the recorded global precipitation mean of $102.2 \mathrm{~cm} \mathrm{year}^{-1}$ (Huffman et al., 1997; Xie et al., 1997). Globally averaged 

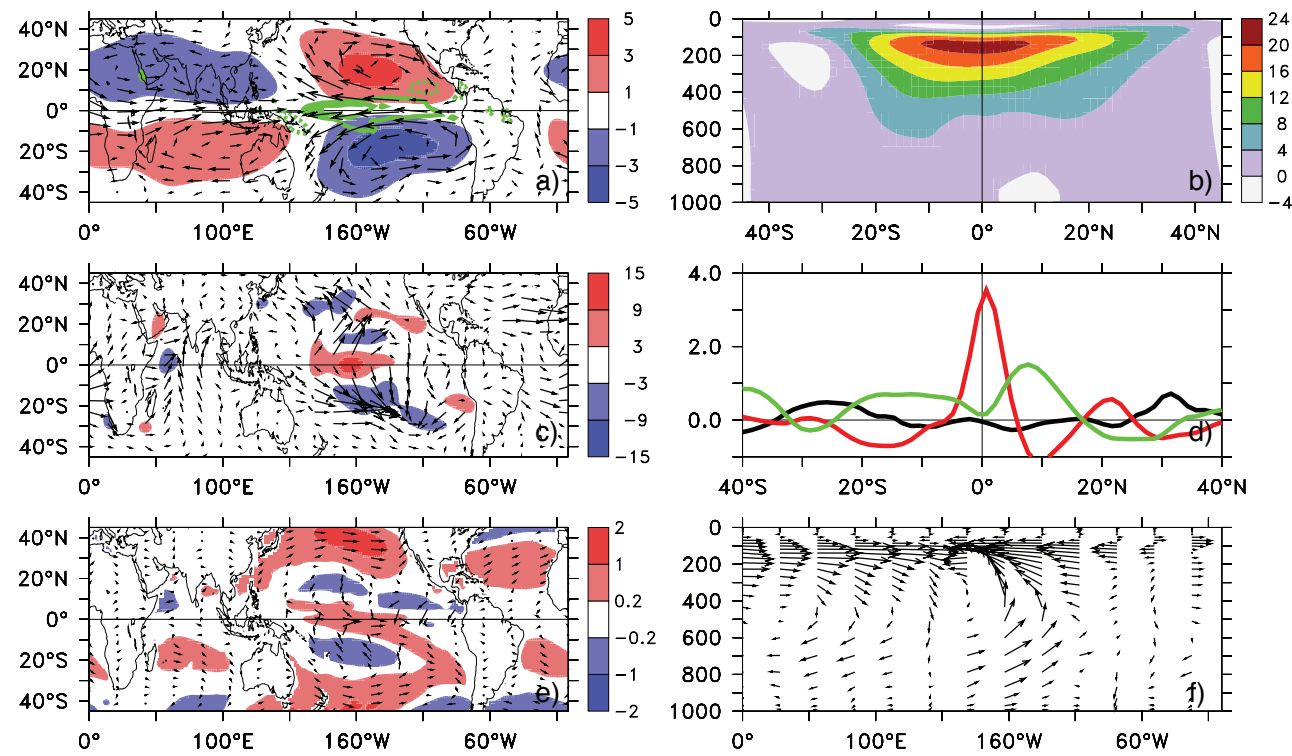

Fig. 4. Annual-mean climatological NINO-MODERN anomalies in the tropical region. (a) Zonally asymmetric component of the streamfunction (shading, units of $10^{7} \mathrm{~m}^{2} \mathrm{~s}^{-1}$ ) and wind (arrows, longest about $30 \mathrm{~m} \mathrm{~s}^{-1}$ ) averaged over 100-200 mb. Green contours show convective precipitation rate at intervals of $10 \mathrm{~mm}_{\text {day }}{ }^{-1}$, negative dashed. (b) Zonal-mean zonal wind ( $\mathrm{m} \mathrm{s}^{-1}$ ). (c) Stationary wave activity flux (arrows, longest about $100 \mathrm{~m}^{2} \mathrm{~s}^{-2}$ ) and its convergence (shading, units of $\mathrm{m} \mathrm{s}^{-1}$ day $^{-1}$ ), averaged over 100-200 mb. (d) Zonal-mean zonal momentum tendency (units of $\mathrm{m} \mathrm{s}^{-1} \mathrm{day}^{-1}$ ). (e) Horizontal wind in the lowest model layer (arrows, longest about $8 \mathrm{~m} \mathrm{~s}{ }^{-1}$ ) and zonal surface wind stress over ocean (shading, units of $0.1 \mathrm{~N} \mathrm{~m}^{2}$ ). (f) Zonally asymmetric component of the zonal-vertical wind in the equatorial region, averaged $5^{\circ} \mathrm{S}-5^{\circ} \mathrm{N}$. Longest arrows indicate a horizontal component of about $20 \mathrm{~m} \mathrm{~s}^{-1}$; vertical (pressure) velocity component has been multiplied by -100 for display purposes.

precipitation increases by $2.7 \%$ in the NINO case (relative to the MODERN case), as compared to $0.2 \%$ change for typical El Niño events (Dai and Wigley, 2000).

This large response is due to small differences between the surface energy budget of the two cases, which must be accounted for by enhanced evaporation and hence enhanced precipitation. Tests with a different control case with identical surface energy budget reveal that all the results discussed in this paper are, however robust and not affected by this imbalance.

Annual precipitation increases in central South America, Eastern Australia, Southern Africa, and over Europe in the NINO case (relative to MODERN) (Fig. 2b). Annual precipitation decreases are seen in northern South America, the Central East African coast, and Southern India. The spatial pattern of the precipitation anomalies (Fig. 2c) is consistent with previous research analyzing satellite and rain gauge data (Dai and Wigley, 2000), and is consistent with the blueprint argument (Molnar and Cane, 2002).

\subsection{Annual-mean planetary-scale circulation and superrotation}

Annual-mean sea level pressure (SLP) decreases in the NINO case (relative to the MODERN case) by $10-15 \mathrm{mb}$ in the North Pacific, and by $2-4 \mathrm{mb}$ in the North Atlantic
(Fig. 2e). Deepening of the Aleutian low in the North Pacific is typical for El Niño events, and has been linked to shifts in storm tracks during El Niño winters (Bjerknes, 1969; Namias and Cayan, 1984). This change in atmospheric circulation is also apparent in the $500 \mathrm{mb}$ geopotential height anomalies (Fig. 2f) and in the subtropical jet at $200 \mathrm{mb}$, which intensifies over the central subtropical Pacific by $10-20 \mathrm{~m} \mathrm{~s}^{-1}$, while relaxing over the northern North Pacific (Fig. 2d). Perhaps the most striking feature of Fig. $2 \mathrm{~d}$ is the strong westerly acceleration of winds along the equator, which result in an increase of the zonal-mean zonal wind of over $20 \mathrm{~m} \mathrm{~s}^{-1}$ in the region around the equatorial tropopause (Fig. 4b). Since zonal-mean zonal winds around the equatorial tropopause are close to zero in the MODERN simulation, this means that the NINO simulation has westerlies on the equator, i.e., is in a state of superrotation (Pierrehumbert, 2000).

These changes in the planetary-scale circulation can be interpreted as a response to the imposed shift of warm SSTs into the central and EEP, resulting in a strong increase in convective precipitation there (Fig. 1a, b, c). The consequent increase in tropospheric heating drives a response similar to the classical Matsuno-Gill solution (Fig. 4a) featuring planetary-scale Rossby gyres straddling the equator, which is known to produce superrotation (Showman and Polvani, 2010). However, the NINO minus MODERN response differs from the linear Matsuno-Gill solution in that the gyres 
are shifted east by approximately $1 / 4$ wavelength, so that the upper-level equatorial easterly anomaly coincides with the heating maximum. A similar shift was seen in a simpler model by Kraucunas and Hartmann (2005), who attributed the shift to eastward advection by the strong superrotating mean flow.

The superrotation is attributable to momentum convergence onto the equator by the Rossby gyres themselves, particularly the strong, meridionally phase-tilted Pacific gyres. This can be seen by examining the wave activity flux, a standard diagnostic of stationary Rossby wave propagation (Plumb, 1985). Figure 4c shows prominent wave activity flux anomalies emanating from the region of anomalous heating and propagating poleward in both hemispheres, implying a convergence of zonal momentum onto the central equatorial Pacific. In the zonal mean (Fig. 4d), this results in an anomalous acceleration of around $4 \mathrm{~m} \mathrm{~s}^{-1}$ day $^{-1}$, leading to superrotation. This value is averaged over $100-200 \mathrm{mb}$ due to mean vorticity flux $(f+\bar{\zeta}) \bar{v}$, where $f$ is the Coriolis parameter, $\bar{\zeta}$ is the zonal-mean relative vorticity, and $\bar{v}$ is the zonal-mean meridional velocity, stationary eddy momentum flux convergence, and transient eddy momentum flux convergence.

In the modern climate, zonally-concentrated heating in the western equatorial warm pool drives a Matsuno-Gill type response which is observed to converge momentum onto the equator, though too weakly to produce true superrotation (Dima et al., 2005). Past modeling studies of the permanent El Niño state (Barreiro et al., 2006; Shukla et al., 2009; Vizcaino et al., 2010) used equatorial SST anomalies which effectively removed the zonal SST gradient in the equatorial Pacific and did not show superrotation. In our case, the imposed SST anomaly is strong enough to create an SST maximum in the central Pacific (Fig. 2a), whose concentrated heating is strong enough to drive superrotation. Past work using GCMs with zonally-localized equatorial heating anomalies (Hoskins et al., 1999; Inatsu et al., 2002) has also shown equatorial superrotation. Recently, Caballero and $\mathrm{Hu}-$ ber (2010) also found a transition to superrotation in warm climate simulations due to equatorial Rossby wave momentum convergence; however, in that case the waves were transient waves reminiscent of the modern Madden-Julian Oscillation, and thus quite different from the imposed, stationary anomaly of the present study.

The presence of strong, anticyclonic phase-shifted gyres in the subtropical central Pacific has several consequences; one is the jet anomalies noted in Fig. 2c that affect the climate of North America (see below). Another consequence is that because the Matsuno-Gill response corresponds to the first baroclinic mode, the central Pacific equatorial upperlevel easterlies are mirrored by near-surface equatorial westerlies (Fig. 4e). Overall, the equatorial Pacific response to the permanent El Niño forcing is a reversed Walker cell, with ascent east of the dateline and descent to its west (Fig. 4f). The presence of strong westerly surface wind stress on the equa- tor is consistent with expectations of a permanent El Niño state, and could help stabilize this state in the presence of atmosphere-ocean coupling.

\subsection{Regional seasonal temperature and precipitation patterns}

Annual mean surface air temperature decreases over most of the continental US in the NINO case in the high-resolution RegCM3 simulations (Fig. 5a). Temperature decreases over the southeastern and southwestern US in SeptemberOctober-November (SON), while warming occurs over the Pacific Northwest (Fig. 5b). In addition, negative surface pressure anomalies occur over the east and west coasts, indicating changes in stormtrack direction and intensity in response to the permanent El Niño forcing. Surface air temperature decreases are isolated to the southeast and southwest in December-January-February (DJF), with temperatures increasing over the Pacific Northwest (Fig. $5 \mathrm{c}$ ) and into Canada, which can be seen clearer in the global temperature plots. This response is induced by increased meridional heat transport (Figure not shown). The warming over Canada and Alaska during El Niño events is important for Northern Hemisphere glaciation and has been the focus of previous permanent El Niño research (Huybers and Molnar, 2007; Brierley and Fedorov, 2010). Further, large surface pressure anomalies occur over the west and east coasts in DJF which affect intensity and direction of stormtracks. (Fig. 5c). Cooling occurs over the southern US in March-April-May (MAM) (Fig. 5d), and over most of the continental United States in June-July-August (JJA), along with small positive surface pressure anomalies over the eastern US (Fig. 5e).

Positive anomalies (NINO minus MODERN) in mean annual precipitation occur over the southeastern, western, and northcentral US in the high-resolution RegCM3 simulations (Fig. 6a). Precipitation increases over the east coast, the southeast, and California in SON (Fig. 6b), while precipitation increases are isolated to the east coast, California and parts of the southwest in DJF. Wind anomalies in DJF suggest increased moisture transport from the sub-tropical Pacific in the NINO case (relative to the MODERN case) (Fig. 6c). Precipitation anomalies are similar in MAM and DJF over most of the US (Fig. 6d), with the exception of positive anomalies over the central United States in April, which coincides with the onset of springtime convective precipitation (Castro et al., 2001; Barlow, 2000). Precipitation increases over the southeast, the central US, and the Pacific Northwest in JJA (Fig. 6e). Cyclonic circulation anomalies occur off of the south Atlantic coast in JJA, indicating a change in the summer monsoon circulation in response to the permanent El Niño forcing (see discussion in Sect. 4.2). 


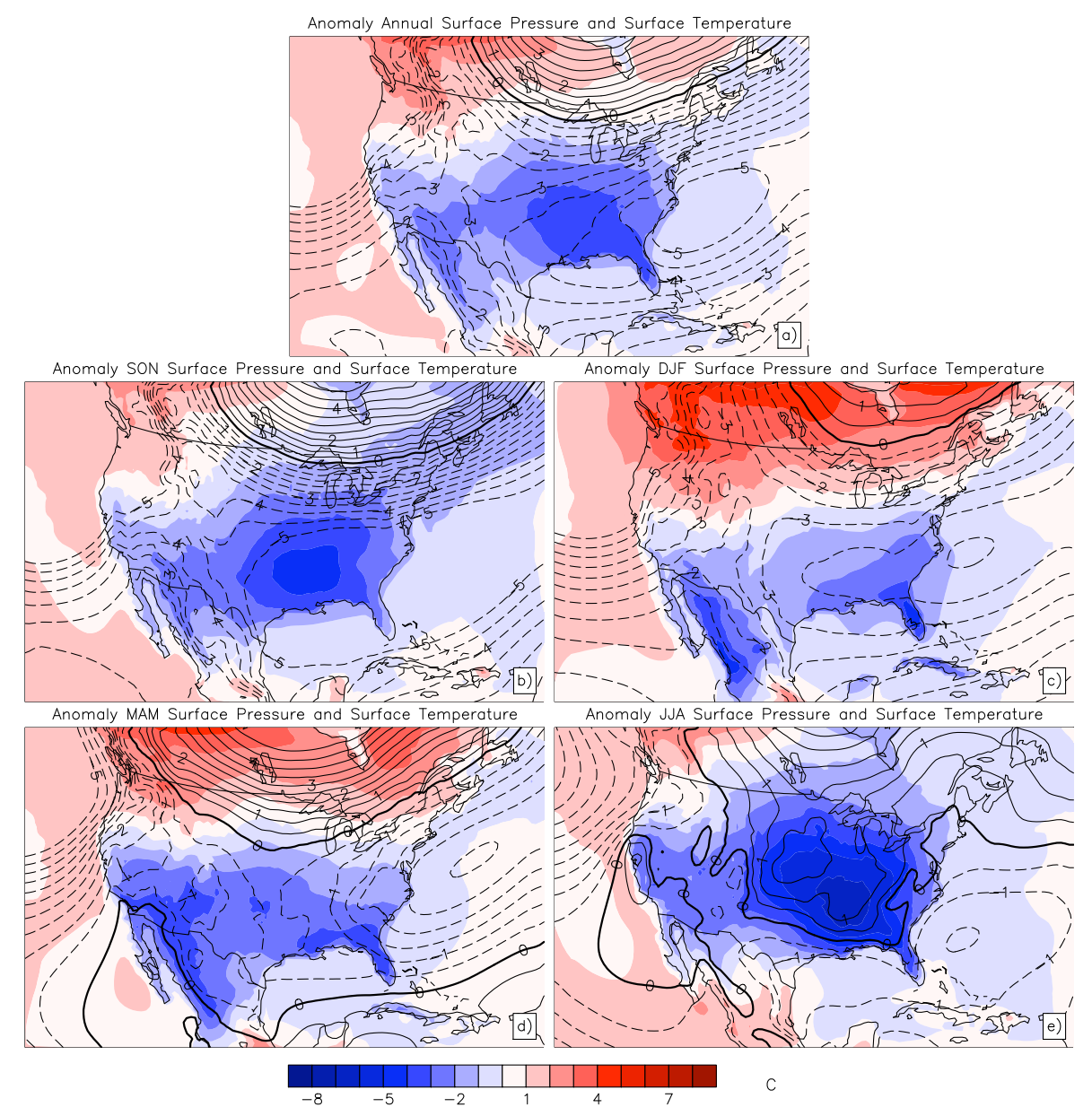

Fig. 5. Temperature anomalies $\left({ }^{\circ} \mathrm{C}\right)$ for NINO minus MODERN from RegCM3 results. (a) Mean annual anomaly, (b) September, October, November (SON) anomaly, (c) December, January, February (DJF) anomaly, (d) March, April, May anomaly, (e) June, July, August anomaly. Contour lines represent pressure anomalies in $\mathrm{mb}$, where negative values are dashed, positive values are constant, and thick black line is the zero contour.

\subsection{Global and regional seasonal circulation changes}

We focus on shifts in boreal winter, spring, and summer circulation emphasizing the CAM3 GCM results during DJF (when large-scale features dominate the hydroclimatic response to permanent El Niño-like forcing in the US), and the RegCM3 nested climate model results during MAM and JJA (when regional-scale features influence the hydroclimatic response).

\subsubsection{Large-scale circulation changes}

The jet stream steers synoptic storms into western North America during El Niño events (Diaz et al., 2001). To describe the changes in atmospheric circulation during boreal winter, we quantify changes in the atmospheric jet and the subsequent changes in moisture transport into North America. The southward shift in the Pacific and Atlantic stormtrack is evident in the $200 \mathrm{mb}$ mean zonal wind for the NINO case (Fig. 7a) relative to the MODERN case (Fig. 7b). Bo- real winter mean zonal wind increases over the west and east coast of the US, resulting in a displaced jet that should advect more moisture into the continental United States.

To quantify the changes in moisture transport we decompose the moisture flux into the mean component $(\bar{U} \bar{Q})$ and $(\bar{V} \bar{Q})$ and transient eddy response $\left(\overline{U^{\prime} Q^{\prime}}\right)$ and $\left(\overline{V^{\prime} Q^{\prime}}\right)$ over North America, utilizing standard meteorological definitions of the reynolds decomposition for scalar and vector fields. We then calculate the vertically integrated moisture flux convergence by the time mean and transient eddy component (Fig. 8). The integrated moisture flux for the time mean circulation is calculated by integrating the convergence of the time mean quantities for $(\bar{U} \bar{Q})$ and $(\bar{V} \bar{Q})$ over the entire atmospheric column. The transient eddy integrated moisture flux is calculated by subtracting the time averaged fields from instantaneous fields, and then doing the integration of the transient eddy convergence over the entire atmospheric column (Higgins et al., 1997; Castro et al., 2001). 


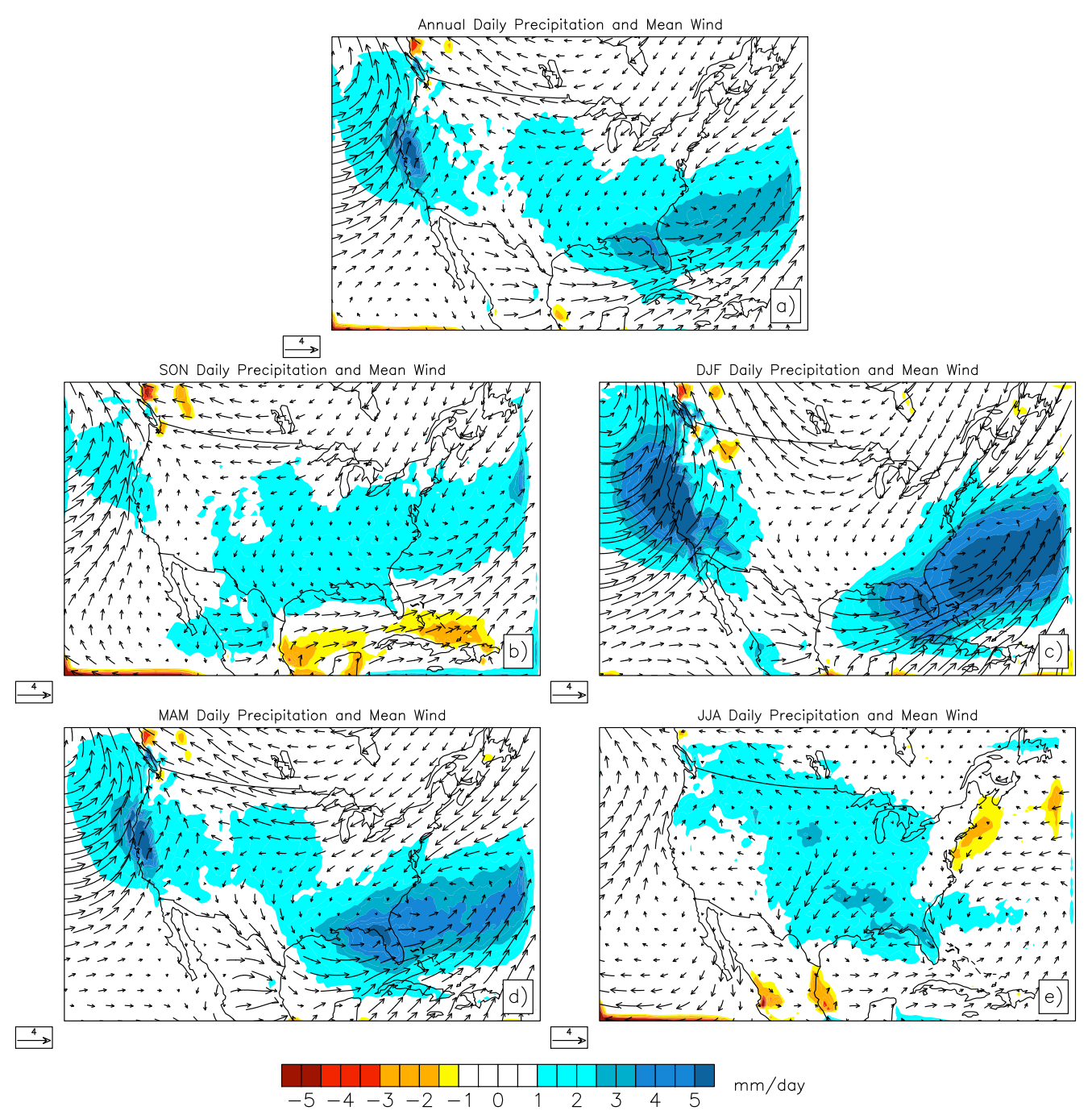

Fig. 6. Precipitation anomalies (mm day ${ }^{-1}$ ) for NINO minus MODERN from RegCM3. (a) Mean annual anomaly, (b) SON precipitation anomalies, (c) DJF precipitation anomalies, (d) MAM precipitation anomalies, and (e) JJA precipitation anomalies. Vectors are placed over the precipitation contours and represent mean wind $\left(\mathrm{m} \mathrm{s}^{-1}\right)$ at lowest model level. The data is plotted to show only the statistically significant anomalies at the $95 \%$ confidence interval.

Results show that the integrated moisture flux by the mean flow increases over the western US, but not over the east coast of the United States in the NINO case (Fig. 8a) relative to MODERN (Fig. 8b). When taking the anomaly between the NINO and MODERN case, this results in an anomalous increase in the integrated moisture flux convergence over the western US and an increase in moisture flux by the mean wind directed toward the western United States (Fig. 8c).

The transient eddy integrated moisture flux in the NINO case exhibits a southward shift in the integrated moisture flux over the east and west coasts of the United States (Fig. 8d, e). The NINO case has increases in the integrated moisture flux in the east coast of the United States, and the transient eddy moisture flux is directed from the central Atlantic toward the east coast of the United States (Fig. 8e). The transient eddy integrated moisture flux does not increase over the west coast of the United States, indicating that the increases in precipitation over the western US are not induced by the transient eddies.

In summary, the precipitation over the west and east coasts of the US are controlled by different mechanisms. The mean integrated moisture flux is responsible for the increases in precipitation over the western US (Fig. 8c) as the mean zonal wind shifts southward, altering the amount of moisture entering the western United States. On the east coast, the transient eddies direct moisture onshore, increasing the integrated moisture flux (Fig. 8f) and precipitation (Fig. 6c). 

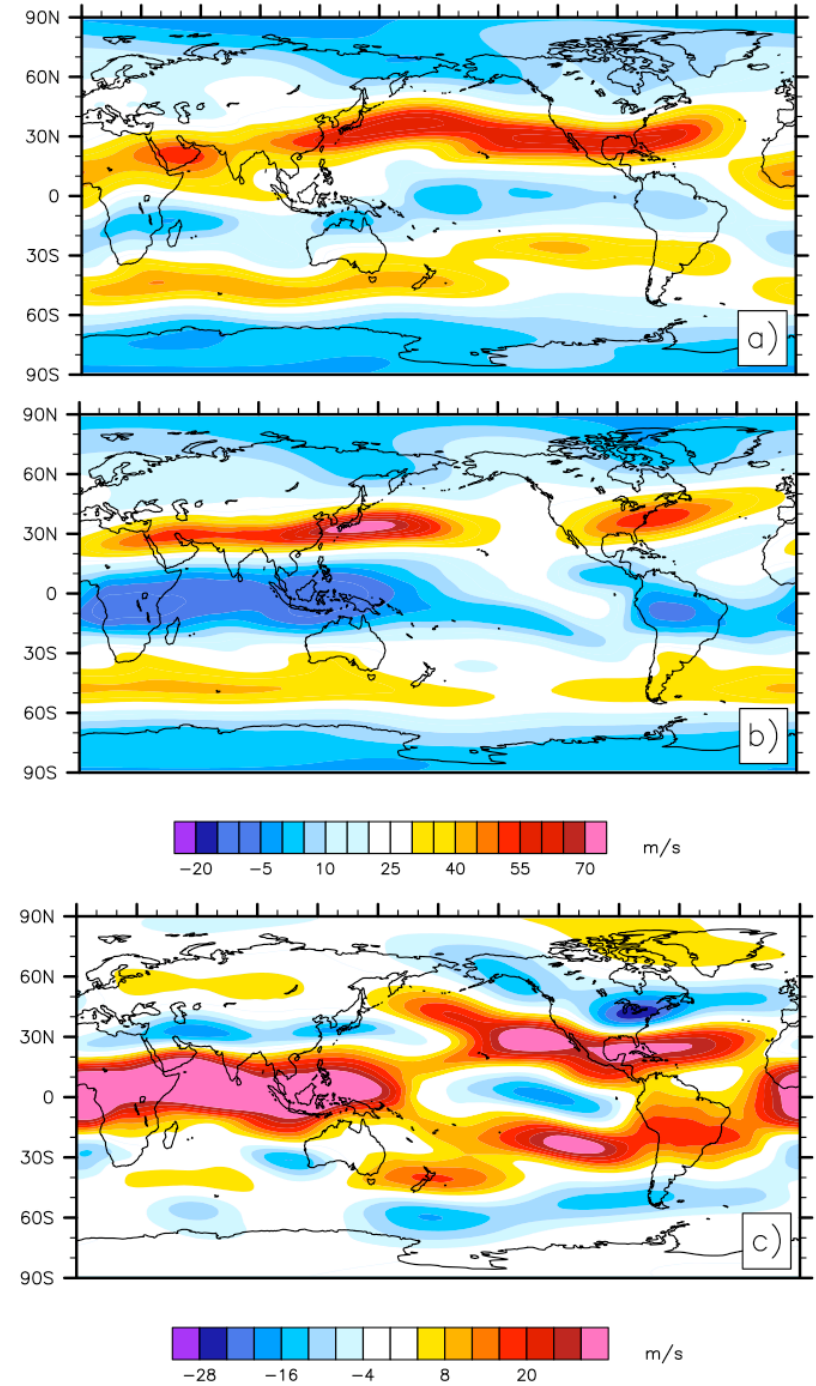

Fig. 7. Boreal winter average of mean wind $\left(\mathrm{m} \mathrm{s}^{-1}\right)$ interpolated to the $200 \mathrm{mb}$ pressure level. (a) The NINO case, (b) MODERN case, and (c) difference between NINO and MODERN.

\subsubsection{Regional-scale circulation and precipitation variability}

Motivated by previous work suggesting the importance of fine-scale processes in shaping the regional-scale climate response to changes in global radiative forcing (Diffenbaugh et al., 2006, 2005; Rauscher et al., 2008; Ashfaq et al., 2010), we use the high-resolution RegCM3 model to test the role of fine-scale climate processes in shaping the regional hydroclimatic response to permanent El Niño-like SSTs. Here we analyze the RegCM3 results to explore the regional precipitation and circulation anomalies that develop in the boreal spring and boreal summer due to a permanent El Niño. Analysis will aim to explain the seasonality of precipitation anomalies, the lower level circulation, and moisture availability over the United States.
We present the month by month precipitation anomalies because the spring precipitation is linked to increases in soil moisture values and summertime precipitation. The March precipitation anomalies (NINO minus MODERN) have a similar spatial pattern to the DJF precipitation anomalies, with the largest anomalies occurring over the east and west coasts of the US and indicating an active stormtrack throughout the boreal springtime (Fig. 9a). The magnitude of the positive precipitation anomalies over the central US persists through August, while the magnitude of the anomalies over the coasts progressively decay each month through the spring and summer (Fig. 9).

To isolate changes in available water vapor, we examine the vertically integrated moisture $(Q)$ in the upper atmosphere $\sim 850 \mathrm{mb}$ and above and the lower atmosphere $\sim 850 \mathrm{mb}$ and below. The upper atmospheric moisture is decreased in the NINO case over the midwestern and southeast US in JJA (Fig. 10a). The upper-level $(200 \mathrm{mb})$ circulation indicates that the sub-tropical jet is intensified as the mean wind increases over the Rocky Mountains (Fig. 10a). The integrated moisture content between $\sim 850 \mathrm{mb}$ and the surface results in increased moisture availability in the NINO case compared with the MODERN case, indicating enhanced moisture availability in the lower atmosphere in the NINO case. In addition, cyclonic circulation anomalies develop over the central US in JJA (Fig. 10b), which induces increases in summertime precipitation due to enhanced atmospheric instability. The increases in lower level integrated moisture, enhanced cyclonic flow over the eastern half of the US, and increased sub-tropical jet over the central US explain why precipitation is increased over central US in response to permanent El Niño forcing.

In summary, winter-like dynamics persist in the Pacific sector until late spring, causing a southward shift in stormtracks which induces precipitation increases over the east and west coast of the United States. During boreal summer, increases in moisture availability in the lower atmosphere and a shift in lower level mean wind allow convective precipitation to entrain deep into the continental United States. These mechanisms are integral in increasing precipitation in the US in boreal spring and summer.

\subsubsection{Secondary soil moisture feedbacks}

Previous research has shown that wet springtime months can lead to an enhanced summertime precipitation (Eltahir, 1998; Findell and Eltahir, 1997, 2003; Pal and Eltahir, 2002), and regional climate modeling experiments have been run which explore these types of feedbacks. Fischer et al. (2007) explored the feedbacks of soil moisture on the large European drought of 2003 and found that by decreasing the soil moisture quantities, this increased the strength of the European drought and induced secondary atmospheric circulation feedbacks. Seneviratne et al. (2006) used a regional model where they turned off the land-atmosphere interactions and found 

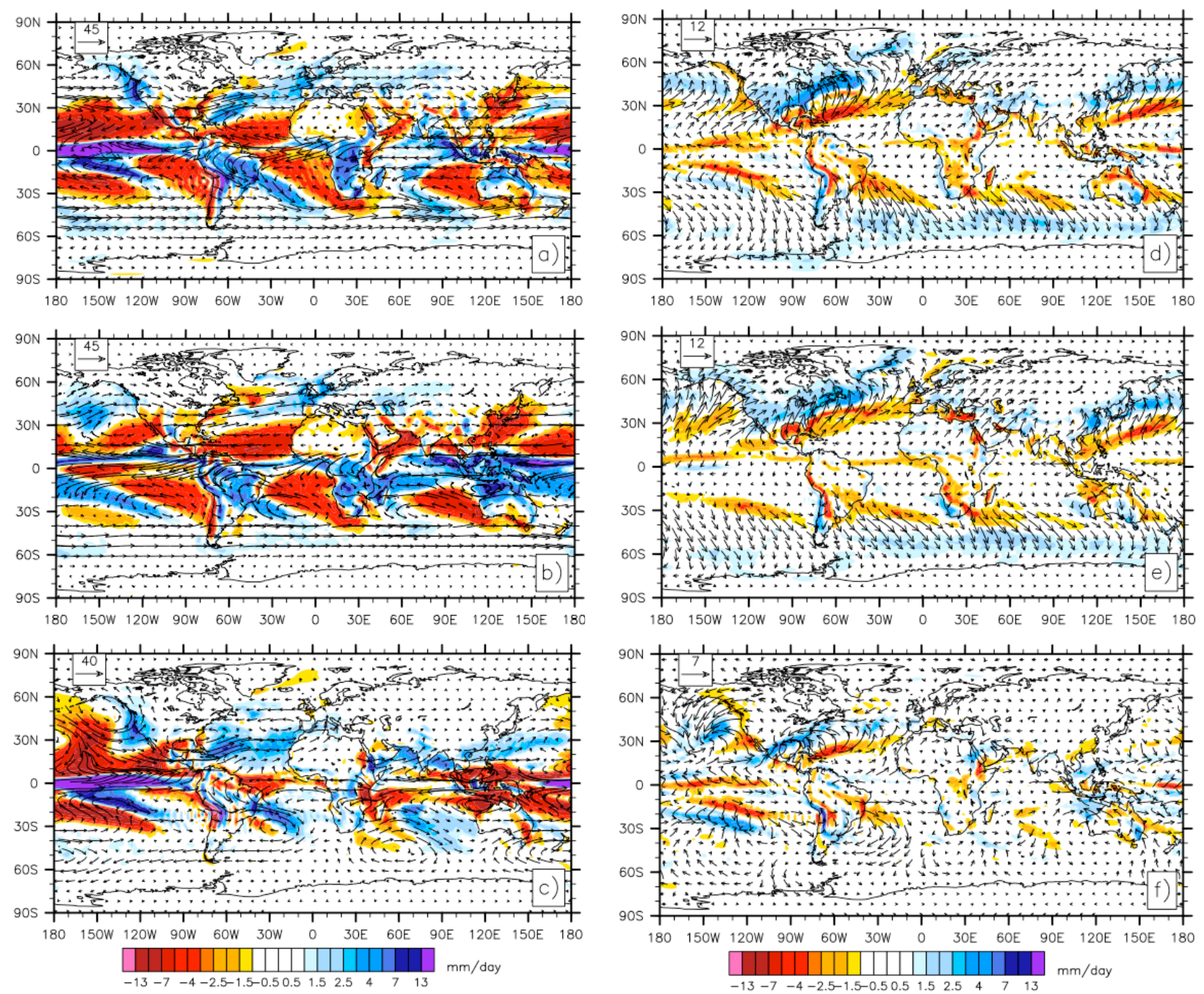

Fig. 8. Boreal winter mean vertically integrated moisture flux convergence (mm day $\left.{ }^{-1}\right)$ with moisture transport $(\bar{U} \bar{Q})$ and $(\bar{V} \bar{Q})$ by mean winds $\left(\mathrm{g} \mathrm{kg}^{-1} \mathrm{~mm} \mathrm{day}^{-1}\right.$ ) overlain as vectors on the $850 \mathrm{mb}$ pressure surface. (a) Mean vertically integrated moisture flux convergence for NINO case, (b) Mean integrated moisture flux convergence for MODERN case, and (c) Mean vertically integrated moisture flux convergence anomaly for NINO minus MODERN. Boreal winter transient eddy vertically integrated moisture flux convergence $\left(\mathrm{mm} \mathrm{day}^{-1}\right)$ with moisture flux by transient eddies $\left(\overline{U^{\prime} Q^{\prime}}\right)$ and $\left(\overline{V^{\prime} Q^{\prime}}\right)\left(\mathrm{g} \mathrm{kg}^{-1} \mathrm{~mm} \mathrm{day}^{-1}\right)$ overlain as vectors on the $850 \mathrm{mb}$ pressure surface. (d) Transient eddy vertically integrated moisture flux convergence for NINO case, (e) Transient eddy integrated moisture flux convergence for MODERN case, and (f) Transient eddy vertically integrated moisture flux convergence anomaly for NINO minus MODERN.

that this feedback is extremely important in understanding climate change in a world with increased atmospheric carbon dioxide. These studies illustrate that the land surface feedbacks resolved in regional models are important in controlling precipitation and atmospheric circulation. Also as described above in the seasonality of precipitation, the longer memory introduced into the regional climate system by the winter precipitation anomalies causes spring and summer to be moister. These results motivate why we show the seasonality of precipitation and its relationship with soil soil moisture feedbacks.
In our experiments, the NINO case relative to the MODERN case has increased surface soil moisture in the Pacific Northwest and midwestern US starting in April and stays elevated throughout JJA. To explore the connection between soil moisture and precipitation, we lag correlated soil moisture and different atmospheric variables by averaging May through August and lagging precipitation and relative humidity against the May through August average of soil moisture contents (Fig. 11). We show correlations for the NINO test case only because in the MODERN simulation none of the lag correlations were statistically significant. 


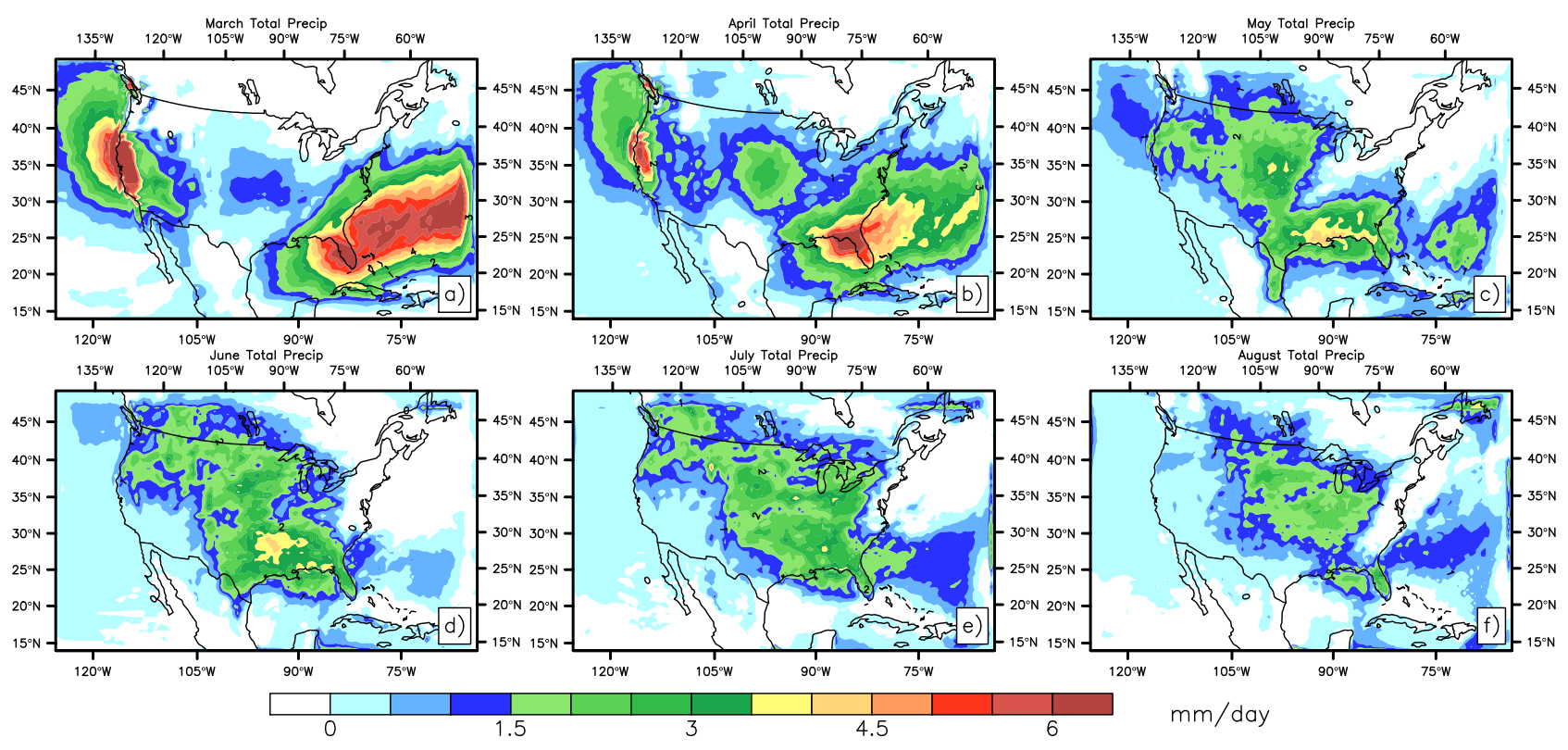

Fig. 9. RegCM3 precipitation anomalies decomposed into single months ( $\mathrm{mm} \mathrm{day}^{-1}$ ) for boreal spring and and boreal summer for NINO minus MODERN. Plots are (a) March, (b) April, (c) May, (d) June, (e) July, and (g) August.

We correlate soil moisture to precipitation to see if increases in soil moisture may be causing increases in rainfall during boreal summer. Figure 11 shows the correlations between soil moisture $(\mathrm{mm})$ and precipitation and plots the correlations at lag 0,1,2 where precipitation lags soil moisture in Fig. 11b, c. Lag 0 shows a large correlation between soil moisture and precipitation across the entire contiguous US, with largest correlations of 0.8 occurring south of $30^{\circ} \mathrm{N}$ (Fig. 11a). This pattern is especially seen over the Southeast where soil moisture and precipitation both increase in the NINO case, but not in the MODERN case.

Lag correlations are calculated with soil moisture lagging by 1 and 2 months and plotted between ( -0.3 and 0.3$)$. At a lag 1 month, soil moisture and precipitation are positively correlated in the Pacific Northwest and the southeast (Fig. 11b). The correlation of $0.2-0.3$ indicates a relationship between soil moisture values in May with increases in precipitation seen in June. When precipitation is lagging by 2 months, a positive correlation exists in the Pacific Northwest and the southeast (Fig. 11c), but the correlation begins to diminish and is gone at lag of 3 months. These positive correlations seen in the Pacific Northwest and in the southeast do not show up in the MODERN simulation. Results show that at a lag of 1 and 2 months, soil moisture values in the Pacific Northwest and southeast may be related to precipitation values in June. Both of these regions see statistically significant increases in precipitation during JJA, and this indicates that the soil moisture feedback may be a secondary feedback in the system, but most likely is not a dominant driver in increasing precipitation due to a permanent El Niño.
The correlation analysis was also calculated between soil moisture and relative humidity for the NINO simulation. The geographic areas of statistically significant results remain the same as the results presented above, but the magnitude is increased in the relative humidity and soil moisture correlations.

\subsection{Model proxy comparison}

A compilation of proxy records for the Miocene and Pliocene were gathered and compared with the permanent El Niño induced precipitation anomalies at the global and regional scale (Fig. 1). This analysis is an extension to the proxy comparison completed in Molnar and Cane (2007). In this compilation we have increased the amount of proxy records for the eastern United States and added additional sources in the western United States compared to previous compilations. In broad strokes, the proxy records match the permanent El Niño driven precipitation values very well over North America, South America, Northeast Africa (Bonnefille, 2010), Mediterranean regions (JimenezMoreno et al., 2010), Canada (White et al., 1997), and Indonesia (Amijaya and Littke, 2005). The model precipitation does not match records as well over Central Africa (deMenocal, 1995), parts of Asia (Sun et al., 2010), and Japan (Heusser and Morley, 1996) (Fig. 1a). When comparing with the schematic of Molnar and Cane (2002), the model data comparison matches, with the exception of Central Africa where our model results are drier than the proxy record (deMenocal, 1995). Wetter conditions are seen in North America, Europe, northwestern and southeastern South America, 

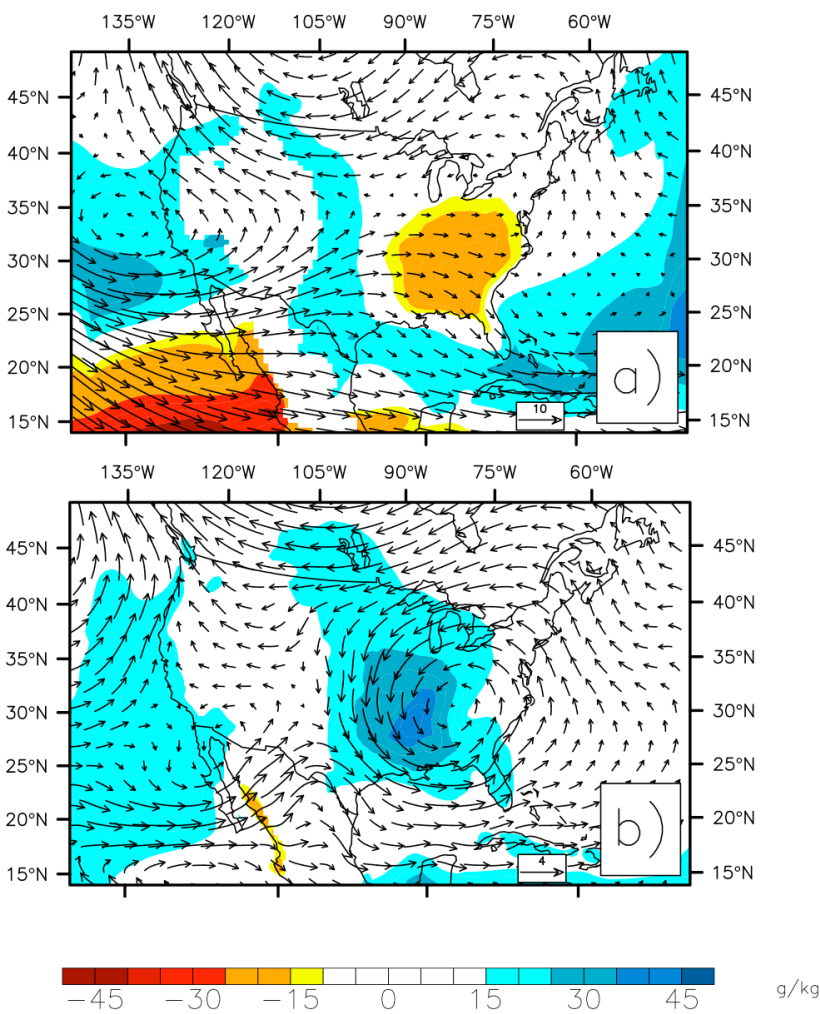

Fig. 10. NINO minus MODERN total column integrated moisture content subtracted from lower ( $\sim 850$ to surface) integrated moisture isolating moisture content in the upper atmosphere $\left(\mathrm{g} \mathrm{kg}^{-1}\right)$. (a) Upper integrated moisture for boreal summer, with the vectors representing mean wind $\left(\mathrm{m} \mathrm{s}^{-1}\right)$ anomaly between NINO and MODERN plotted at model level $3(\sim 200 \mathrm{mb})$. (b) Lower integrated moisture content $(\sim 850$ to surface) for boreal summer. Mean wind is plotted at model level $16(\sim 850 \mathrm{mb})$. The plots are statistically significant data at the $95 \%$ confidence interval.

and drier conditions are seen in northeastern South America (Fig. 1a). In addition, Australia has contradictory reconstructions for precipitation, but our results do match the areas of drying seen in Metzger and Retallack (2010) and mentioned in Molnar and Cane (2002).

In order to develop a more detailed knowledge of the past pattern of hydrological change, we perform a higher resolution model-data comparison. A regional scale precipitation and proxy comparison was completed over the US using RegCM3 (Fig. 1b). While preparing the comparison significant effort was devoted to locating inferred precipitation records over the eastern United States. To date, previous studies focused on temperature differences (Cronin and Dowsett, 1991) between the Neogene warm periods and modern (Molnar and Cane, 2002, 2007; Bonham et al., 2009). Using proxies and vegetation cover described in Braun (1950), Martin and Harrell (1957), and Litwin and Andrle (1992), results show expansive deciduous and temperate forests in the eastern United States. It was inferred by those authors that this climate and vegetation cover could only be sustained by increased modern rainfall in the Miocene and early Pliocene (Fig. 1b). Increased precipitation along the eastern US is also suggested by Willard et al. (1993), but this study also indicates little change of precipitation in Florida. The modeled permanent El Niño precipitation over the eastern US is able to capture this wetter pattern seen in the proxy records.

The western US has received substantial attention by climate scientists and geologists because of its susceptibility to large-scale droughts (Cook et al., 2004; Cole et al., 2002). Most proxy records in the western US for the Neogene warm periods indicate wetter than modern with the exception of Thompson (1991) and Retallack (2004), which suggest drier conditions in the Pacific Northwest in the late Pliocene. The simulated response of precipitation to permanent El Niñolike SSTs captures the wetter-than-present conditions inferred from the proxy data. The regional model simulates more wide-spread moistening in the western and central US than the global model, and the drier conditions over the Pacific Northwest indicated by Thompson (1991) and Retallack (2004) are resolved in the regional model, but not in the global model (Fig. 1). In addition, comparison of the highresolution regional model and the lower-resolution global model suggests that topographic complexity influences not only the baseline precipitation of the western US but also the regional response of precipitation to the El Niño SST forcing, with reduced moistening on the lee side of the Pacific-coast high elevations. However, the spatial contrasts in magnitude of moistening are not testable with the proxy reconstruction shown here.

\section{Discussion}

\subsection{Boreal winter storm track changes}

We find that permanent El Niño-like forcing depresses boreal winter SLP in the North Pacific and shifts southward the jet stream in both the Pacific and the Atlantic. This type of atmospheric response during an El Niño event is very similar to past teleconnection research (Horel and Wallace, 1981; Held et al., 1989; Straus and Shukla, 1997). With this being said, precipitation anomalies induced by El Niño in the boreal winter depend heavily on the type of SST forcing in the EEP (Trenberth and Smith, 2009). Because our imposed El Niño SST pattern resembles the "Modoki" (dateline centered) and "canonical" (more EEP centered), our precipitation and temperature results end up looking like a combination of El Niño modes as described in Trenberth and Smith (2009).

Furthermore, the decreases in EKE in the North Pacific indicate less storm activity, but the increases in the mean integrated moisture flux convergence and southward shift in mean zonal wind off the west coast of the US allow moisture 


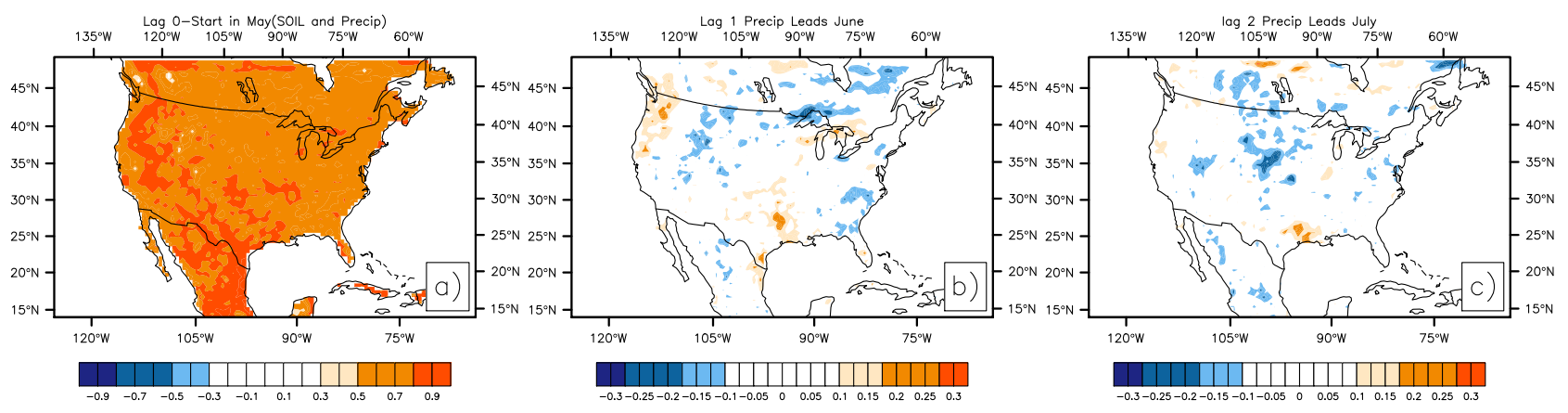

Fig. 11. Plots $(\mathbf{a}-\mathbf{c})$ show the correlation between soil moisture for the topmost layer in $(\mathrm{mm})$ and precipitation $\left(\mathrm{mm}^{-1 a y}{ }^{-1}\right)$ for the NINO simulation only. Correlations are calculated with lag of zero (a) which represents the climatological average for May-August (soil moisture) versus May-August (precipitation). Plot (b) is precipitation lagging by one month, May-August (soil moisture) versus June-September (precipitation). Plot (c) is precipitation lagging by 2 months, May-August (soil moisture) versus July-November (precipitation). The data is plotted to incorporate only the statistically significant data at the $95 \%$ confidence interval.

advection to penetrate deeper into western North America. The deepened low pressure in the Atlantic stormtrack induces increases in the transient moisture flux from the Atlantic, ultimately leading to increases in rainfall over the east coast of the United States.

The shifts in atmospheric circulation seen during the boreal winter persists into the boreal spring. As a result, the permanent El Niño forcing produces large increases in precipitation off the west and east coasts of the US during boreal spring into early summer. This response leads to increases in soil moisture values that induce secondary land surface feedbacks, discussed in further detail below.

\subsection{Permanent El Niño and summertime precipitation patterns}

The permanent El Niño-like forcing increases summertime precipitation in the US through a number of mechanisms. These mechanisms include: (1) shifts in regional circulation that increase moisture availability in the southeast US, (2) strengthening of the sub-tropical jet that can control the northward extent of summertime precipitation, and (3) wetter conditions during the springtime that can lead to feedbacks which help to enhance summertime precipitation.

Specifically, summertime precipitation is enhanced due to availability of water vapor that is transported into the southeast and midwestern US due to shifts in regional-scale atmospheric circulation and increases in lower-atmospheric moisture. Over the eastern US, $500 \mathrm{mb}$ geopotential height decreases along with an increase in the subtropical jet over the Rocky Mountains (Fig. 11a). Increased moisture availability is seen as far north as $45^{\circ} \mathrm{N}$, indicating that moisture is able to penetrate deep into the continental interior because of the movement of the jet stream. In addition, the anomalous precipitation during the spring helps to create a more efficient environment for summertime precipitation over the southeast and Pacific Northwest via persistence introduced by soil moisture.

Previous research has shown that the summertime precipitation can shift due to negative geopotential height fluctuations and the development of cyclonic flow over the midwestern US (Mechoso et al., 2005). Other studies have shown that summertime precipitation is enhanced due to increased moisture flux from the Gulf of Mexico caused by a displaced intertropical convergence zone (ITCZ) (Mechoso et al., 2005; Higgins and Shi, 2001), or by changes in the subtropical jet, which can effectively pull moisture out of the Gulf of Mexico (Trenberth and Guillemot, 1996). Our results are consistent with studies describing mechanisms that cause summertime precipitation anomalies due to El Niño (Trenberth and Guillemot, 1996; Pal et al., 2000; Pal and Eltahir, 2002; Mechoso et al., 2005).

Summertime precipitation patterns associated with the North American Monsoon (NAM) have been linked to El Niño events (Castro et al., 2001). A constant ENSO forcing could create a more efficient transfer of heat from the tropics to the mid latitudes due to the development of eddies and movement of Rossby waves affecting stormtracks that can drive the advection of warm moist air from the Gulf of Mexico during boreal summer (Trenberth et al., 1998; Oort et al., 1996). Our simulations indicate a weaker NAM controlled by the development of northeasterly winds over the Great Plains controlled by the low pressure system which develops over the east coast.

In boreal summer, our NINO induced temperature and precipitation anomalies over North America result in a cooler and wetter southeastern US when compared to modern observations (Barlow et al., 2000). Interestingly, when the NINO anomalies are compared against some CMIP3 El Niño modeling studies, the temperature and precipitation patterns seen over North America are spatially similar, but our anomalies are intensified especially for precipitation and temperature (Mo, 2010). 


\subsection{Permanent El Niño and a connection to past and future climate}

As described in Sect. 2.1, differences in topography and vegetation are important in shaping these Neogene climate periods (e.g., Haywood et al., 2004; Herold et al., 2008; You et al., 2009; Bonham et al., 2009). Research has shown that altering vegetation cover in Pliocene climate simulations results in model precipitation matching most of the proxy reconstructions (Bonham et al., 2009). Still, this study had a hard time matching the wetter conditions indicated by the proxy record over the east coast of the US. The permanent El Niño induced precipitation anomalies presented in our results match the pattern seen in the majority of global records and more specifically over the west and the east coast of the US. In future work, proper Neogene vegetation needs to be prescribed in the US in a RegCM3 permanent El Niño simulation to fully understand the hydrologic cycle feedbacks. Prescribing vegetation like the inferred temperate forests on the east coast (Pound et al., 2011) and tropical forests on the west coast (Salzmann et al., 2009) should induce positive feedbacks and will help in describing why conditions were wetter than modern over North America throughout the Neogene (Thompson, 1991, 1996; Smith and Patterson, 1993; Smith, 1994; Wolfe, 1994, 1997; Axelrod, 1997; Braun, 1950; Willard et al., 1993; Litwin and Andrle, 1992).

One motivation for using RegCM3 is to illustrate how precipitation changes over topography in comparison to the coarser global model because resolving precipitation over uplift regions is important in characterizing Neogene hydrologic cycles. Moving forward, the inclusion of realistic paleo-topography in Neogene climate simulations is necessary. Here we conducted a sensitivity experiment that posed to address how a permanent El Niño affects hydroclimatology, leaving the inclusion of correct paleo-topography for future work. An important conclusion from RegCM3 results is that precipitation patterns are sensitive to topography, ergo the development of paleo-topography over North America for the Neogene time periods is important.

Coupled global climate models generally do not show a transition into a permanent El Niño SST pattern in warmer climates (Haywood et al., 2007; Huber and Caballero, 2003; Galeotti et al., 2010). This motivated us to prescribe SSTs in the EEP because coupled models are usually unable to reach this equilibrium state. A number of recent studies have explored mechanisms capable of sustaining a permanent El Niños in climate models (Fedorov et al., 2010; Sriver and Huber, 2010). These studies have shown that vertical ocean mixing can push the EEP into a more El Niño-like state (Fedorov et al., 2010; Sriver and Huber, 2010). These modeling studies give a plausible physical mechanism for the permanent El Niño and expanded warm pool in the EEP that has been inferred from Pliocene proxy records (Ravelo et al.,
2004; Brierley et al., 2009), but more work is necessary to prove this hypothesis.

Other work has suggested that a transition to superrotation could contribute to a permanent El Niño state through weakening of the trade winds (Tziperman and Farrell, 2009). Our experiments have shown that the presence of a strong, persistent El Niño anomaly causes superrotation and contributes to a reversal of the trade winds, i.e., to surface westerlies along the Equatorial Pacific. This constitutes a potential positive feedback loop that could produce a stable, large-amplitude permanent El Niño state. Further investigation of this supperrotation hypothesis will require additional experiments with fully-coupled ocean-atmosphere climate models.

\section{Conclusions}

By using a high-resolution global general circulation model and nested regional model, here we explored the possible atmospheric dynamics that could develop if the ocean was in a permanent El Niño-like mean state. Results from this study sensitivity show that changes in tropical Pacific SSTs provide one possible explanation for this aridity paradox between past and future climate in the subtropical dry zones. Our teleconnection response generally agrees with the hydrologic cycle blueprint presented by Molnar and Cane (2002) as seen in the model and proxy comparison. The modeled precipitation anomaly matches the proxy record well over North and South America and the Mediterranean and European regions. The modeled precipitation does not do as well over Australia and Central Africa. Furthermore, the NINO induced precipitation anomalies are able to explain the majority of North American proxy record, which has been a difficult for previous studies to describe.

More novely, we give a detailed seasonal analysis quantifying why the precipitation anomalies develop using both a global and a high resolution regional model. The increases in precipitation can be explained by a shift in atmospheric circulation in all seasons. During boreal winter the Aleutian low deepens, and the $200 \mathrm{mb}$ jet intensifies and shifts southward. The boreal winter precipitation anomalies over the western US are induced by increased moisture flux convergence by the mean flow, while the positive precipitation anomalies in eastern US are induced by increased moisture flux by eddies. This atmospheric response in the Pacific and Atlantic persists into MAM, increasing summertime precipitation and soil moisture values all year round.

During boreal summer, precipitation increases are associated with shifts in the upper atmospheric jet and increased atmospheric moisture availability, while feedbacks from spring soil moisture to summer precipitation are relatively weak. This shift in boreal summer circulation does not seem to be associated to an intensification of NAM and leads to large scale increases in precipitation over the entire eastern United States. Further, our experiments indicate that persistent El 
Niño-like conditions with an El Modoki-like central Pacific SST maximum could result in supperrotation and a reversal of the trade winds, a mechanism that could help to explain past periods in which climate proxies suggest a permanent El Niño mean state.

Acknowledgements. We thank Ki-Hong Min, Michael Alexander, and Ruben van Hooidonk for their helpful suggestions during preparation of this manuscript. We acknowledge support of the Computational Sciences and Engineering (CS\&E) program which supports the first author through a GAANN fellowship. In addition, parts of this research were funded by NSF grants, EAR-0450221 and OCE-0902882. This is PCCRC paper number 1108. We also acknowledge significant improvement of the manuscript by reviewers especially Dorian Abbot who pointed out issues with our prior analysis and editor Nerilie Abram.

Edited by: N. Abram

\section{References}

Amijaya, H. and Littke, R.: Microfacies and depositional environment of Tertiary Tanjung Enim low rank coal, South Sumatra Basin, Indonesia, Int. J. Coal Geol., 61, 197-221, 2005.

Ashfaq, M., Shi, Y., Tung, W.-W., Trapp, R. J., Gao, X., Pal, J. S., and Diffenbaugh, N. S.: Suppression of South Asian summer monsoon precipitation in the 21 st century, Geophys. Res. Lett., 36, L01704, doi:10.1029/2008GL036500, 2009.

Ashfaq, M., Bowling, L. C., Cherkauer, K. A., Pal, J. S., and Diffenbaugh, N. S.: Influence of climate model biases and daily-scale temperature and precipitation events on hydrological impacts assessment: A case study of the United States, J. Geophys. Res.Atmos., 115, D14116, doi:10.1029/2009JD012965, 2010.

Ashok, K., Behera, S. K., Rao, S. A., Weng, H., and Yamagata, T. El Niño Modoki and its possible teleconnection, J. Geophys. Res., 112, C11007, doi:10.1029/2006JC003798, 2007.

Axelrod, D. I.: Tertiary floras and topographic history of the Snake River Basin, Idaho, Bull. Geol. Soc. Am., 79, 713-733, 1968.

Axelrod, D. I.: Outline history of California vegetation, in: Terrestrial Vegetation of California, edited by: Barbour, M. and Major, J., New York, John Wiley and Sons, 139-193, 1997.

Barlow, M., Nigam, S., and Berber, E. H.: ENSO, Pacific decadal variability, and US summertime precipitation, drought, and streamflow, J. Climate, 14, 2105-2128, 2000.

Barreiro, M., Philander, G., Pacanowski, R., and Fedorov, A.: Simulations of warm tropical conditions with application to middle Pliocene atmospheres, Clim. Dynam., 26, 349-365, doi:10.1007/s00382-005-0086-4, 2006.

Bjerknes, J.: Atmospheric teleconnections from the Equatorial Pacific, Mon. Weather Rev., 97, 163-172, 1969.

Bonham, S., Haywood, A., Lunt, D., Collins, M., and Salzmann, U.: El Nino-Southern Oscillation, Pliocene climate and equifinality, Philosophical Transactions of the Royal Society A., 367(1886), 127, doi:10.1098/rsta.2008.0212, 2009.

Bonnefille, R.: Cenozoic vegetation, climate changes and hominid evolution in tropical Africa, Global Planet. Change, 72, 390-411, doi:10.1016/j.gloplacha.2010.01.015, 2010.
Boyd, A.: Relict conifers from the mid-Pleistocene of Rhodes, Greece. Historical Biology, An International Journal of Paleobiology, 21, 1-15, doi:10.1080/08912960903033301, 2009.

Braun, E. L.: Deciduous forests of eastern North America, Hafner Publishing Co., New York and London, 596, 1950.

Brierley, C. M., Fedorov, A. V., Liu, Z., Herbert, T. D., and Lawrence, K. T., and La Riviere, J. P.: Greatly expanded tropical warm pool and weakened Hadley circulation in the early Pliocene, Science, 323, 1714-1718, 2009.

Brierley, C. M. and Fedorov, A. V.: The relative importance of meridional and zonal SST gradients for the onset of the ice ages and Pliocene-Pleistocene climate evolution, Paleoceanography, 25, PA2214, doi:10.1029/2009PA001809, 2010.

Caballero, R. and Huberm, M.: Spontaneous transition to superrotation in warm climates simulated by CAM3, Geophys. Res. Lett., 37, L11701, doi:10.1029/2010GL043468, 2010.

Castro, C. L., McKee, T. B., and Pielke Sr, R. A.: The relationship of the North American Monsoon to Tropical and North Pacific Sea surface temperatures as revealed by observational analyses, J. Climate, 14, 4449-4473, 2001.

Chamberlain, C. P. and Poage, M. A.: Reconstructing the paleotopography of mountain belts from the isotopic composition of authigenic minerals, Geology, 28, 115-118, 2000.

Chiang, J. C. H.: The tropics in paleoclimate, Annu. Rev. Earth. Pl. Sc., 37, 263-297, 2009.

Cole, J. E., Overpeck, J. T., and Cook, E. R.: Multiyear La Nina events and persistent drought in the contiguous US, Geophys. Res. Lett., 29, 1647, doi:10.1029/2001GL013561, 2002.

Collins, W. D., Bitz, C. M., Blackmon, M. L., and Bonan, G. B.: The Community Climate System Model: CCSM3, J. Climate, 19, 212-214, doi:10.1175/JCLI3761.1, 2006.

Collins M., An S-S, Cai W., Ganachaud A., Guilyardi E., Jin FF, Jochum M., Lengaigne M., Power S., Timmermann A., Vecchi G., and Wittenberg A.: The impact of global warming on the tropical Pacific Ocean and El Niño, Nat. Geosci., 3, 391-397, doi:10.1038/ngeo868, 2010.

Cook, E. R., Woodhouse, C. A., Eakin, C. M., Meko, D. M., and Stahle, D. W.: Long-term aridity changes in the western US, Science, 306, 1015-1018, 2004.

Clark M. K., Maheo G., Saleeby J., an dFarley K. A.: The nonequilibrium landscape of the southern Sierra Nevada, California, GSA Today 15: 4-10, 2005.

Crowley, T. J.: Pliocene climates: the nature of the problem, Mar. Micropaleontol., 27, 3-12, doi:10.1016/0377-8398(95)00049-6, 1996.

Cronin, T. M.: Pliocene shallow water paleoceanography of the North Atlantic Ocean based on marine ostracodes: Quaternary Sci. Rev., 10, 175-188, doi:10.1016/0277-3791(91)90017-O, 1991.

Dai, A. and Wigley, T. M. L.: Global patterns of ENSO-induced precipitation, Geophys. Res. Lett., 27, 1283-1286, 2000.

Dekens, P. S., Ravelo, A. C., and McCarthy, M.: Warm upwelling regions in the warm Pliocene, Paleoceanography, 22, PA3211, doi:10.1029/2006PA001394, 2007.

Dekens, P. S., Ravelo, A. C., McCarthy, M. D., and Edwards, C. A.: A 5 million year comparison of $\mathrm{Mg} / \mathrm{Ca}$ and alkenone paleothermometers, Geochem. Geophys. Geosy., G3(9), Q10001, doi:10.1029/2007GC001931, 2008.

deMenocal, P. B.: Plio-Pleistocene African climate, Science, 270, 
53-59, 1995.

Diaz, H. F., Hoerling, M. P., and Eischeid, J. K.: ENSO variability, teleconnections and climate change, Int. J. Climatol., 21, 18451862,2001

Diffenbaugh, N. S., Krupke, C, H., White, M. A., and Alexander, C. E.: Global warming presents new challenges for maize pest management, Environ. Res. Lett., 3, 044007, doi:10.1088/1748-9326/3/4/044007, 2008.

Diffenbaugh, N. S. and Ashfaq, M.: Intensification of hot extremes in the US, Geophys. Res. Lett., 37, L15701, doi:10.1029.GL043888, 2010.

Diffenbaugh, N. S., Pal, J. S., Trapp, R. J., and Giorgi, F.: Finescale processes regulate the response of extreme events to global climate change, P. Natl. Acad. Sci., 102, 15774-15778, 2005.

Diffenbaugh, N. S., Ashfaq, M., Shuman, B., Williams, J. W., and Bartlein, P. J.: Summer aridity in the US: response to midHolocene changes in insolation and sea surface temperature, Geophys. Res. Lett., 33, L22712, doi:10.1029/2006GL028012, 2006

Dima, I. M., Wallace, J. M., and Kraucunas, I.: Tropical zonal momentum balance in the NCEP reanalyses, J. Atmos. Sci., 62, 2499-2513, 2005.

Dowsett, H. J., Barron, J., and Poore, R.: Middle Pliocene sea surface temperatures: a global reconstruction, Mar. Micropaleontol., 27, 13-26, 1996.

Eltahir, E. A.: A soil moisture rainfall feedback mechanism 1., Theory and observations, Water Resour. Res., 34, 765-776, 1998.

Fedorov, A. and Philander, G.: Is El Niño changing?, Science, 288, 1977-2002, 2000.

Fedorov, A. V., Dekens, P. S., McCarthy, M., Ravelo, A. C., deMenocal, P. B., Barreiro, M., Pacanowski, R. C., and Philander, S. G.: The Pliocene paradox (Mechanisms for a permanent El Niño), Science, 312, 1485-1489, doi:10.1126/science.1122666, 2006.

Fedorov, A. V., Brierley, C. M., and Emanuel, K.: Tropical cyclones and permanent El Niño in the early pliocene epoch, Nature, 463, 1066-1070, doi:10.1038/nature08831, 2010.

Findell, K. L. and Eltahir, E. A.: An analysis of the soil moisture rainfall feedback, based on direct observations from Illinois, Water Resour. Res., 33, 725-735, 1997.

Findell, K. L. and Eltahir, E. A. B.: Atmospheric controls on soil moisture-boundary layer interactions, Part Feedbacks within the Continental U.S., J. Hydrometeorol., 4, 570-583, 2003.

Fischer, E. M., Seneviratne, S. I., Vidale, P. L., Lüthi, D., and Schär, C.: Soil Moisture Atmosphere Interactions during the 2003 European Summer Heat Wave. J. Climate, 20, 5081-5099. doi:10.1175/JCLI4288.1, 2007.

Forester, R. M.: Pliocene-climate history of the western US derived from lacustrine ostracodes, Quat. Sci. Rev., 10, 133-146, 1991.

Galeotti, S., von der Heydt, A., Huber, M., Bice, D., Dijkstra, H., Jilbert, T., Lanci, L., and Reichart G. J.: Evidence for active El Nino Southern Oscillation variability in the Late Miocene greenhouse climate, Geology, 38, 419-422, doi:10.1130/G30629.1, 2010.

Graham, A.: Late tertiary paleoaltitudes and vegetational zonation in Mexico and Central America, Acta Bot. Neerl., 38, 417-424, 1989.

Hack, J. J., Caron, J. M., Yeager, S. G., Oleson, K. W., Holland, M. M., Truesdale, J. E., and Rasch, P. J.: Simulation of the global hydrological cycle in the CCSM community atmosphere model version 3 (CAM3): mean features, J. Climate, 19, 2199 2221, doi:10.1175/JCLI3755.1, 2006.

Hansen, J., Sato, M., Ruedy, R., Lo, K.,Lea, D. W., and Medina-Elizade, M.: "Global Temperature Change", Proceedings of the National Academy of Sciences, 103, 14288-14293, doi:10.1073/pnas.0606291103, 2006.

Haywood, A. M. and Valdes, P. J.: Modelling middle Pliocene warmth: contribution of atmosphere, oceans and cryosphere, Earth Planet Sc. Lett., 218, 363-377, doi:10.1016/S0012821X(03)00685-X, 2004.

Haywood, A. M., Valdes, P. J., and Peck, V. L.: A permanent El Niño-like state during the Pliocene?, Paleoceanography, 22, PA1213, doi:10.1029/2006PA001323, 2007.

Held, I. M. and Soden, B. J.: Robust responses of the hydrological cycle to global warming, J. Climate, 19, 5686-5699, doi:10.1175/JCLI3990.1, 2006.

Held, I. M., Lyons, S. W., and Nigam, S.: Transients and the extratropical response to El Niño, J. Atmos. Sci., 46, 163-174, 1989.

Herold, N., Seton, M., Mueller, R. D., You, Y., and $\mathrm{Hu}-$ ber, M.: Middle Miocene tectonic boundary conditions for use in climate models, Geochem. Geophy. Geosy., 9, Q10009, doi:10.1029/2008GC002046, 2008.

Heusser, L. and Morley, J.: Pliocene climate of Japan and environs between 4.8 and 2.8 Ma: A joint pollen and marine faunal study, Mar. Micropaleontol., 27, 86-106, 1996.

Higgins, R. W. and Shi, W.: Intercomparison of the principal modes of interannual and intraseasonal variability of the North American monsoon system, J. Climate, 14, 403-417, 2001.

Higgins, R. W., Yao, Y., Yarosh, E. S., Janowiak, J. E., and Mo, K. C.: Influence of the Great Plains Low-Level Jet on Summertime Precipitation and Moisture Transport over the Central United States, J. Climate, 10, 481-507, doi:10.1175/15200442(1997)010<0481:IOTGPL > 2.0.CO;2, 1997.

Horel, J. D. and Wallace, J. M.: Planetary-scale atmospheric phenomena associated with the Southern Oscillation, Mon. Weather Rev., 109, 813-829, 1981.

Hoskins, B., Neale, R., Rodwell, M., and Yang, G.: Aspects of the large-scale tropical atmospheric circulation, Tellus A, 51, 33-44, 1999.

Huber, M., and Caballero, R.: Eocene El Niño: Evidence for Robust Tropical Dynamics in the "Hothouse", Science, 299, 877-881, 2003.

Huffman, G. J, Adler, R. F, Arkin, P. A, Chang, A., Ferraro, R., Gruber, A., Janowiak, J., McNab, A., Rudolf, B., and Schneider, U.: The Global Precipitation Climatology Project (GPCP) combined precipitation dataset, B. Am. Meteorol. Soc., 78, 5-20, 1997.

Hurrell, J. W. and Trenberth, K. E.: Global sea surface temperature analyses: multiple problems and their implications for climate analysis, modeling, and reanalysis, B. Am. Meteorol. Soc., 80, 2661-2678, 1999

Hurrell, J. W., Hack, J. J., Phillips, A. S., Caron, J., and Yin, J.: The dynamical simulation of the community atmosphere model version 3 (CAM3), J. Climate, 19, 2162-2183, doi:10.1175/JCLI3762.1, 2006.

Huybers, P. and Molnar, P.: Tropical cooling and the onset of North American glaciation, Clim. Past, 3, 549-557, doi:10.5194/cp-3549-2007, 2007.

Inatsu, M., Mukougawa, H., and Xie, S.: Stationary eddy response 
to surface boundary forcing: idealized GCM experiments, J. Atmos. Sci., 59, 1898-1915, 2002.

Jimenez-Moreno, G., Fauquette, S., and Suc, J. P.: Miocene to Pliocene vegetation reconstruction and climate estimates in the Iberian Peninsula from pollen data, Review of Palaeobotany and Palynology, 162, 403-415, 2010.

Joseph, R. and Nigam, S.: ENSO evolution and teleconnections in IPCCs 20th century climate simulations: realistic representation?, J. Climate, 19, 4360-4377, 2006.

Karnauskas, K., Seager, R., Kaplan, A., Kushnir, Y., and Cane, M. A.: Observed strengthening of the zonal sea surface temperature gradient across the Equatorial Pacific Ocean, J. Climate, 22, 4316-4321, doi:10.1175/2009JCLI2936.1, 2009.

Kraucunas, I. and Hartmann, D.: Equatorial superrotation and the factors controlling the zonal-mean zonal winds in the tropical upper troposphere, J. Atmos. Sci., 62, 371-389, 2005.

Litwin, R. J. and Andrle, V. A. S.: Palynomorph census data from Pliocene strata of the U.S. Atlantic Coastal Plain (Massachusetts to central Florida), U.S. Geol. Surv. Open-File Rep., 92-262, 1992.

Lyle, M., Barron, J., Bralower J., Huber, M, Lyle, A. O., Ravelo, A. C., Rea, R. K., and Wilson, P.: Pacific Ocean and cenozoic evolution of climate, Rev. Geophys., 46, RG2002, doi:10.1029/2005RG000190, 2008.

Martin, P. S. and Harrell, B. E.: The Pleistocene history of temperate biotas in Mexico and eastern U.S., Ecology, 38, 468-480, 1957.

Mechoso, C. R., Robertson, A. W., Ropelewski, C. F., and Grimm, A. M.: The American Monsoon Systems: an Introduction. The Global Monsoon System: Research and Forecast, edited by: Chang, C. P., Wang, B., and Lau, N. C. G., WMO/TD No. 1266 (TMRP Report No. 70), 197-206, 2005.

Meehl, G., Arblaster, J., Lawrence, D., Seth, A., Schneider, E., and Kirtman, B.: Monsoon regimes in the CCSM3, J. Climate, 19, 2482-2495, doi:10.1175/JCLI3745.1, 2006.

Metzer, C. A. and Retallack, G. J.: Paleosol record of Neogene climate change in the Australian Outback, Aust. J. Earth Sci., 57, 871-885, doi:10.1080/08120099.2010.510578, 2010.

Micheels A., Bruch A. A., Uhl D., Utescher T., and Mosbrugger V.: A late Miocene climate model simulation with Echam4/ML and its quantitative validation with terrestrial proxy data, Palaeogeogr. Palaeocl., 253, 267-286, doi:10.1016/j.palaeo.2007.03.042, 2007.

Mo, K. C.: Interdecadal modulation of the impact of ENSO on precipitation and temperature over the U.S., J. Climate, 23, 36393656, 2010.

Molnar, P. and Cane, M. A.: El Niño's tropical climate and teleconnections as a blueprint for pre-Ice Age climates, Paleoceanography, 17, 1021, doi:10.1029/2001PA000663, 2002.

Molnar, P. and Cane, M. A.: Early Pliocene (pre-Ice Age) El Niño like global climate: which El Niño?, Geosphere, 3, 337-365, 2007.

Namias, J. and Cayan, D. R.: El Niño: implications for forecasting, Oceanus 27, 41-47, 1984.

O'Gorman, P. and Schneider, T.: Scaling of Precipitation Extremes over a Wide Range of Climates Simulated with an Idealized GCM Climate, 22, 5676-5685, doi:10.1175/2009JCLI2701.1, 2009.

Oort, A. H. and Yienger, J. J.: Observed interannual variability in the hadley circulation and its connection to enso, J. Climate, 9, 2751-2767, 1996.

Pal, J. S. and Eltahir, E. A.: Pathways relating soil moisture conditions to future summer rainfall within the land-atmosphere system, J. Climate, 15, 1227-1242, 2000.

Pal, J. S. and Eltahir, E. A.: Teleconnections of soil moisture and rainfall during the 1993 midwest summer flood, Geophys. Res. Lett., 29, 1865, doi:10.1029/2002GL014815, 2002.

Pal, J. S., Eltahir, E. A., and Small, E. E.: Simulation of regionalscale water and energy budgets - representation of subgrid cloud and precipitation processes within RegCM, J. Geophys. Res., 105, 29579-29594, doi:10.1029/2000JD900415, 2000.

Pal, J. S., Giorgi, F., Bi, X., Elguindi, N., and Solmon, F.: Regional Climate Modeling for the Developing World: The ICTP RegCM3 and RegCNET., B. Am. Meteorol. Soc., 88, 1395, doi:10.1175/BAMS-88-9-1395, 2007.

Pierrehumbert, R. T.: Climate change and the Tropical Pacific: the sleeping dragon wakes, P. Natl. Acad. Sci., 97, 1355-1358, 2000.

Philander, S. G. and Fedorov, A. V.: Role of tropics in changing the response to Milankovitch forcing some three million years ago, Paleoceanography, 18, 1045, doi:10.1029/2002PA000837, 2003.

Plumb, R.: On the three-dimensional propagation of stationary waves, J. Atmos. Sci., 42, 217-229, 1985.

Pound, M. J., Haywood, A. M., Salzmann, U., Riding, J. B., Lunt, D. J., Hunter, S. J.: A Tortonian (Late Miocene, 11.61-7.25 Ma) global vegetation reconstruction , Palaeogeogr. Palaeocl., 300, 29-45, doi:10.1016/j.palaeo.2010.11.029, 2011.

Rauscher, S. A., Pal, J. S., and Diffenbaugh, N. S.: Future changes in snowmelt-driven runoff timing over the western US, Geophys. Res. Lett., 35, L16703, doi:10.1029/2008GL034424, 2008.

Ravelo, A. C., Andreasen, D. H., Lyle, M., Lyle, A. O., and Wara, M. W.: Regional climate shifts caused by gradual global cooling in the Pliocene epoch, Nature, 429, 263-267, doi:10.1038/nature02567, 2004.

Raymo, M. E., Grant, B., Horowitz, M., and Rau, G. H.: MidPliocene warmth: stronger greenhouse and stronger conveyor, Mar. Micropaleontol., 27, 313-326, 1996.

Retallack, G.J.: Late Miocene climate and life on land in Oregon within a context of Neogene global change, Palaeogeogr. Palaeocl., 214, 97-123, doi:10.1016/j.palaeo.2004.07.024, 2004.

Retallack, G. J.: Cenozoic paleoclimate on land in North America. Journal of Geology 115, 271-294, doi:10.1086/512753, 2007.

Salzmann, U., Haywood, A. M., and Lunt, D. J.: The past is a guide to the future? Comparing Middle Pliocene vegetation with predicted biome distributions for the twenty-first century, Philosophical Transactions of the Royal Society of London, 367, 189204, doi:10.1098/rsta.2008.0200, 2009.

Sang-Wook Y., Jong-Seong, K., Boris, D., Min-Ho, K., Kirtman, B. P., and Fei-Fei, J.: El Niño in a changing climate, Nature, 461, 511-514, doi:10.1038/nature08316, 2009.

Seager, R. and Vecchi, G. A.: Greenhouse warming and the 21 st Century hydroclimate of southwestern North America, P. Natl. Acad. Sci. USA, 21277-21282, doi:10.1073/pnas.0910856107, 2010.

Seager, R., Ting, M., Held, I., Kushnir, Y., Lu, J., Vecchi, G., Huang, H. P., Harnik, N., Leetmaa, A., and Lau, N. C.: Model projections of an imminent transition to a more arid climate in southwestern North America, Science, 316, 1181-1184, doi:10.1126/science.1139601, 2007. 
Seneviratne, S. I., Lüthi, D. L., Litschi, M., and Schär, C.: Land atmosphere coupling and climate change in Europe, Nature, 443, 205-209, doi:10.1038/nature05095, 2006.

Showman, A. P. and Polvani, L. M.: The Matsuno-Gill model and equatorial superrotation, Geophys. Res. Lett., 37, L18811, doi:10.1029/2010GL044343, 2010.

Shukla, S. P., Chandler, M. A., Jonas, J., Sohl, L. E., Mankoff, K., and Dowsett, H.: Impact of a permanent El Niño (El Padre) and Indian Ocean dipole in warm Pliocene climates, Paleoceanography, 24, PA2221, doi:10.1029/2008PA001682, 2009.

Smith, G. A., Wang, Y., Cerling, T. E., and Geissman, J.W.: Comparison of a paleosol-carbonate isotope record to other records of Pliocene early Pleistocene climate in the western United States, Geology, 21, 691-694, 1993.

Smith, G. A.: Climatic influences on continental deposition during late-stage filling of an extensional basin, southeastern Arizona, Geol. Soc. Am. Bull., 106, 1212-1228, doi:10.1130/00167606(1994)1061212:CIOCDD2.3.CO;2, 1994.

Smith, G. R. and Patterson, W. P.: Mio-Pliocene seasonality on the Snake River plain: comparison of faunal and oxygen isotopic evidence, Palaeogeogr. Palaeocl., 107, 291-302, doi:10.1016/0031-0182(94)90101-5, 1993.

Smith, G. I.: Paleohydrologic regimes in the southwestern Great Basin, 0-3.2 my ago, compared with other long records of global climate, Quat. Res., 22, 1-17, 1984.

Sriver, L. and Huber, M.: Modeled sensitivity of upper thermocline properties to tropical cyclone winds and possible feedbacks on the Hadley circulation, Geophys. Res. Lett., 37, L08704, doi:doi:10.1029/2010GL042836, 2010.

Steppuhn, A., Micheels, A., Bruch, A. A., Uhl, D., Utescher, T., Mosbrugger, V.: The sensitivity of ECHAM4/ML to a double $\mathrm{CO}_{2}$ scenario for the Late Miocene and the comparison to terrestrial proxy data, Glob. Planet. Change, 57, 189-212, 2007.

Stewart, D. R. M., Pearson, P. N., Ditchfield, P. W., and Singano, J.M.: Miocene tropical Indian Ocean temperatures:Evidence from three exceptionally preserved foraminiferal assemblages from Tanzania: J. Afr. Earth Sci., 40, 173-189, doi:10.1016/j.jafrearsci.2004.09.001, 2004.

Straus, D. M. and Shukla, J.: Variations of midlatitude transient dynamics associated with ENSO, J. Atmos. Sci., 54, 777-790, 1997.

Sun, Y., An, Z., Clemens, S., Steven, C., Bloemendal J., and Vandenberghe, J.: Seven million years of wind and precipitation variability on the Chinese Loess Plateau. Earth Planet. Sci. Lett., 297, 525-535, doi:10.1016/j.eps1.2010.07.004, 2010.

Thompson, R. S., Pliocene environments and climates in the western U.S., Quat. Sci. Rev., 10, 115-132, 1991.

Thompson, R. S.: Pliocene and early Pleistocene environments and climates of the western Snake River Plain, Idaho. Mar. Micropaleontol., 27, 141-156, doi:10.1016/0377-8398(95)000569, 1996.

Thompson, R. S. and Fleming, R. F.: Middle Pliocene vegetation: reconstructions, paleoclimatic inferences, and boundary conditions for climatic modeling, Mar. Micropaleontol. 27, 13-26, 1996.

Trapp, R. J., Diffenbaugh, N. S., Brooks, H. E., Baldwin, M. E., Robinson, E. D., and Pal, J. S.: Changes in severe thunderstorm environment frequency during the 21 st century caused by anthropogenically enhanced global radiative forcing, P. Natl. Acad.
Sci., 104, 19719-19723, 2007.

Trenberth, K. E. and Guillemot, J.: Physical processes involved in the 1988 drought and 1993 flood in North America, J. Climate, 9, 1288-1298,1996.

Trenberth, K. E. and Hurrell, J. W.: Decadal atmosphere-ocean variations in the Pacific, Clim. Dynam., 9, 303-319, 1994.

Trenberth, K. E., Branstator, G. W., Karoly, D., Kumar, A., Lau, N. C., and Ropelewski, C.: Progress during toga in understanding and modeling global teleconnections associated with tropical sea surface temperatures, J. Geophys. Res., 103, 291324, 1998.

Trenberth, K. E. and Smith, L.: Variations in the three-dimensional structure of the atmospheric circulation with different flavors of El Niño, J. Climate, 22, 2978-2991, 2009.

Tziperman, E. and Farrell, B. F.: The Pliocene equatorial temperature lessons from atmospheric superrotation, Paleoceanography, 24, PA1101, doi:10.1029/2008PA001652, 2009.

Uhl, D., Bruch, A. A., Traiser, C., and Klotz, S.: Palaeoclimate estimates for the Middle Miocene Schrotzburg flora (S-Germany) a multi-method approach, Int. J. Earth Sci., 95, 1071-1085, doi:10.1007/s00531-006-0083-9, 2006.

Vizcaino, M., Rupper, S., and Chiang, J. C. H.: Permanent El Niño and the onset of Northern Hemisphere glaciations: mechanism and comparison with other hypotheses, Paleoceanography, 25, PA2205, doi:10.1029/2009PA001733, 2010.

Walker, M. D. and Diffenbaugh, N. S.: Evaluation of highresolution simulations of daily-scale temperature and precipitation over the United States, Clim. Dynam., 1131-1147, doi:10.1007/s00382-009-0603-y, 2009.

Wara, M. W., Ravelo, A. C., and Delaney, M. L.: Permanent El Niño-like conditions during the Pliocene warm period, Science, 309, 758-761, doi:10.1126/science.1112596, 2005.

Willard, D. A., Cronin, T. M, Ishman, S. E., and Litwin, R. J.: Terrestrial and marine records of climate and environmental change during the Pliocene in subtropical Florida, Geology, 21, 679$682,1993$.

White, J. M., Ager, T. A., Adam, D. P., Leopold, E. B., Liu, G., Jett, H., Scheweger, C. E.: An 18 million year record of vegetation and climate change in northwestern Canada and Alaska: tectonic and global climatic correlates, Palaeogeogr. Palaeocl., 130, 293-306, 1997.

White, M. A., Diffenbaugh, N. S., Jones, G. V., Pal, J. S., and Giorgi, F.: Extreme heat reduces and shifts United States premium wine production in the 21 st century, P. Natl. Acad. Sci, 103, 11217-11222, doi:10.1073/pnas.0603230103, 2006.

Wolfe, J. A.: Tertiary climatic changes at middle latitudes of western North America, Palaeogeogr. Palaeocl., 108, 195-205, 1994.

Wolfe, J. A.: Distribution of major vegetational types during the Tertiary, in: The Carbon Cycle and Atmospheric $\mathrm{CO}_{2}$ Natural Variations Archean to Present, edited by: Sundquist, E. T. and Broecker, W. S., American Geophysical Union, Washington, 357-375, 1985.

Wolfe J. A., Schorn H. E., Forest C. E., and Molnar P.: Paleobotanical evidence for high altitudes in Nevada during the Miocene, Science, 276, 1672-1675, doi:10.1126/science.276.5319.1672, 1997.

Xie, P. and Arkin, P. A.: Global precipitation: a 17-year monthly analysis based on gauge obser vations, satellite estimates, and numerical model outputs, B. Am. Meteorol. Soc., 78, 2539-2558, 
1997.

You, Y., Huber, M., Mueller, D., Poulsen, C. J., and Ribbe, J.: Simulation of the Middle Miocene climate optimum, Geophys. Res. Lett., 36, L04702, doi:10.1029/2008GL036571, 2009.

Zachos, J., Pagani, M., Sloan, L., Thomas, E., and Billups, K.: Trends, rhythms, and aberrations in global climate $65 \mathrm{Ma}$ to present, Science, 292, 686-693, 2001.
Zarate, M. A. and Fasana, J. I.: The Plio-Pleistocene record of the central eastern Pampas, Buenos Aires, Province, Argentina: the Chapadmalal Case Study, Palaeogeogr. Palaeocl., 72, 27-52, 1989. 